Portland State University

PDXScholar

$11-5-1993$

\title{
This Crying Enormity: Impressment as a Factor in Anglo-American Foreign Relations
}

David Scott Thompson

Portland State University

Follow this and additional works at: https://pdxscholar.library.pdx.edu/open_access_etds

Part of the History Commons

Let us know how access to this document benefits you.

Recommended Citation

Thompson, David Scott, "This Crying Enormity: Impressment as a Factor in Anglo-American Foreign Relations" (1993). Dissertations and Theses. Paper 4677.

https://doi.org/10.15760/etd.6562

This Thesis is brought to you for free and open access. It has been accepted for inclusion in Dissertations and Theses by an authorized administrator of PDXScholar. Please contact us if we can make this document more accessible: pdxscholar@pdx.edu. 
AN ABSTRACT OF THE THESIS OF David scott Thompson for Master of Arts in History presented November 5, 1993.

Title: "This Crying Enormity":

Impressment as a Factor in Anglo-American

Foreign Relations

APPROVED BY THE MEMBERS OF THE THESIS COMMITTEE:

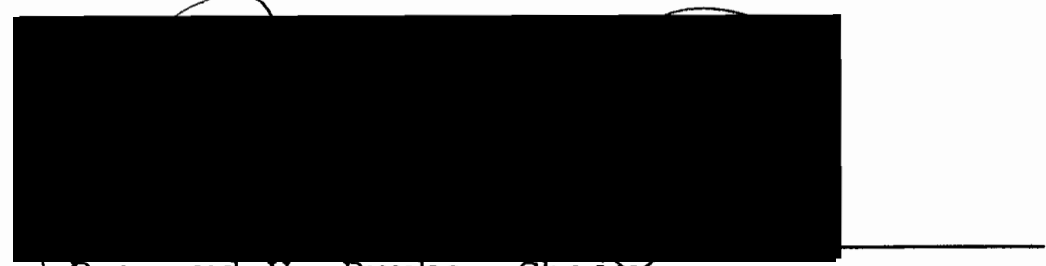

UBernard V. Burke, chair

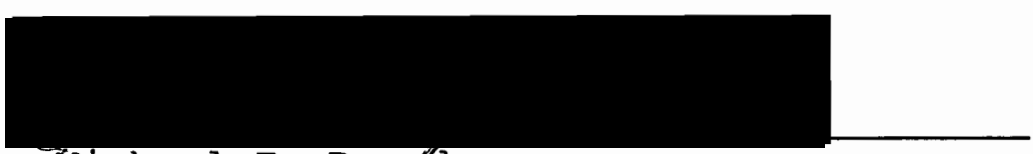

Michael F. Reardon

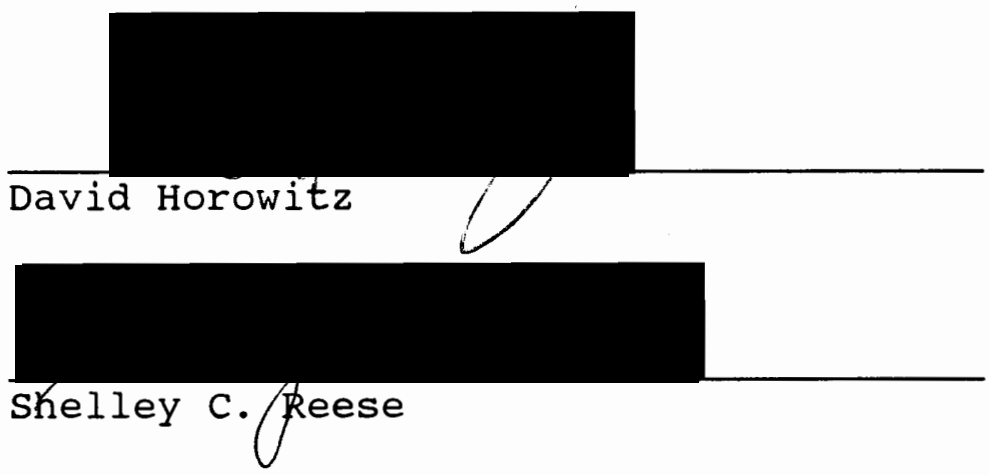

As an issue affecting the foreign relations of the United states and Britain, impressment has been given varying emphasis by different authors. This thesis is first a chronological outline of the events and correspondence that trace the subject. Beyond this basic 
delineation I will consider exactly how important impressment was to the two countries. James F. Zimmerman, in Impressment of American Seamen, posits that impressment was of paramount significance while other authors have attempted to down grade it into a status of utter inconsequence. This paper will show that the actual influence of impressment varied from one time, one set of circumstances, to another. Finally, my thesis will attempt to show more of the British side of the question, heretofore primarily ignored. It will be shown that members of the British government had what they felt to be perfectly valid reasons for continuing the practice, even though it eventually led to war.

Chapter one serves as an introduction and explanation of the legal and historical backgrounds of impressment. The chapter also covers the first difficulties the two countries had over the issue, when England and France nearly went to war in 1787 . These would serve as a model for the problems to come.

Chapter two looks into the reasons behind the need for impressment and America's argument against it. Britain needed men to man the navy, America needed these same men for its merchant marine, out of this the basic conflict was born.

Chapter three deals with American efforts to contain or eliminate impressment, mostly through acts of Congress 
to protect United States sailors. The problem America had with issuing proofs of citizenship and Britain's requirement that America issue them began to bring impressment to the fore. James Monroe was sent to London for talks of which impressment was to be a major topic. Chapter four covers the parallel careers of Monroe, United states envoy to London, and Anthony Merry, British minister to America. Both men had troubles dealing with what they felt were obstinate foreign governments and both mens' missions were, in the end, failures. Merry, feeling America to be inflating the reaction against impressment, paid little attention to the complaints and ended up having to deal with harsh anti-British legislation. Monroe's lack of success took longer and forms the basis of chapter five. This chapter details how the Jefferson administration and Monroe were incapable of getting Britain to give an inch on the subject. This culminated in the Treaty of 1806, which was silent on impressment.

Chapter six shows how this lack of action set the stage for the encounter between the Chesapeake and the Leopard. This skirmish almost led to war and represents the peak of impressment's importance as an issue in foreign affairs.

Chapter seven details other differences between the two countries as they slid toward the war of 1812 . 
Impressment was but one of many causes of the conflict, though one which both sides contributed to keeping alive. Finally, chapter eight covers war-time diplomacy and shows how impressment quickly became the only subject the two countries were fighting over. Later actions on America's part reveal that impressment, as a single complaint, was no longer considered a war-worthy topic, or even much of a cause for complaint. 
"THIS CRYING ENORMITY":

IMPRESSMENT AS A FACTOR IN ANGLO-AMERICAN

FOREIGN RELATIONS

by

DAVID SCOTT THOMPSON

A thesis submitted in partial fulfillment of the requirements for the degree of

MASTER OF ARTS

in

HISTORY

Portland State University

1993 
TO THE OFFICE OF GRADUATE STUDIES:

The members of the Committee approve the thesis of David Scott Thompson presented November 5, 1993.

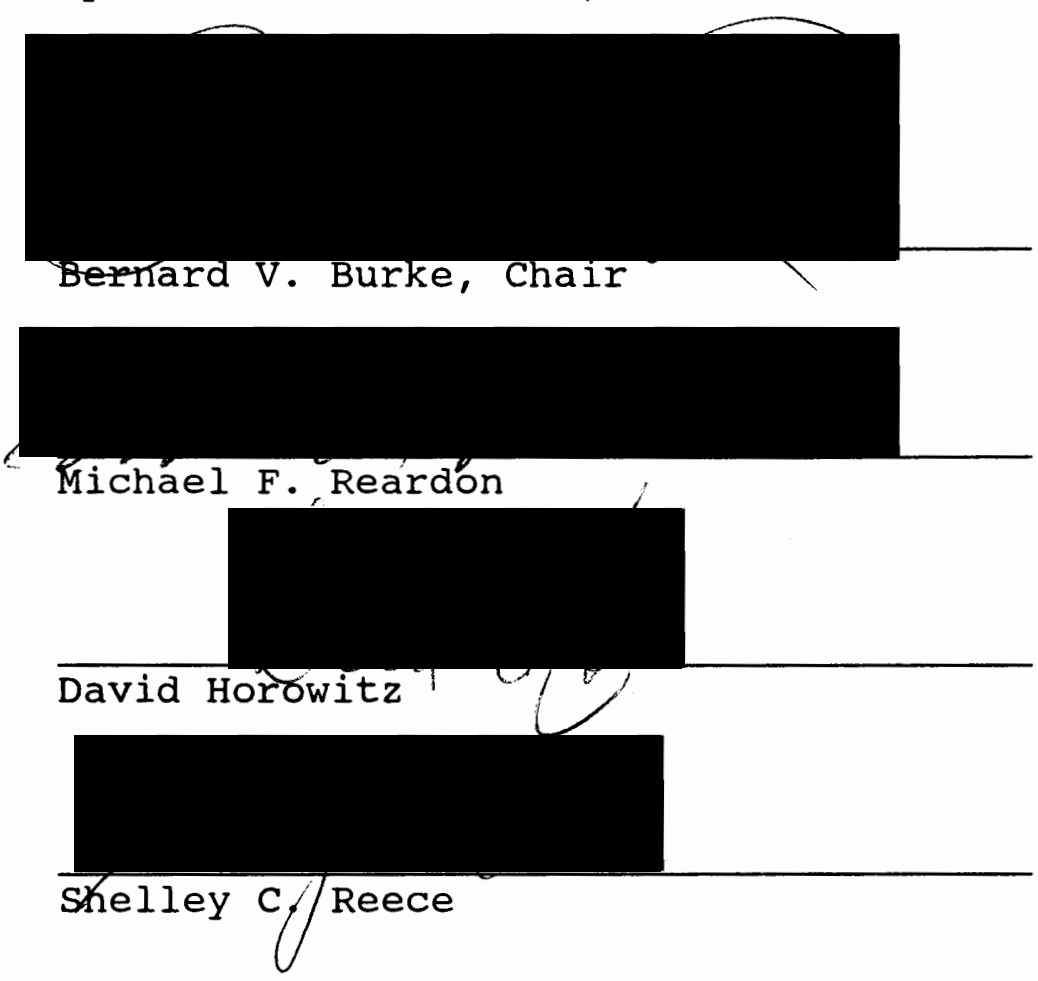

APPROVED:

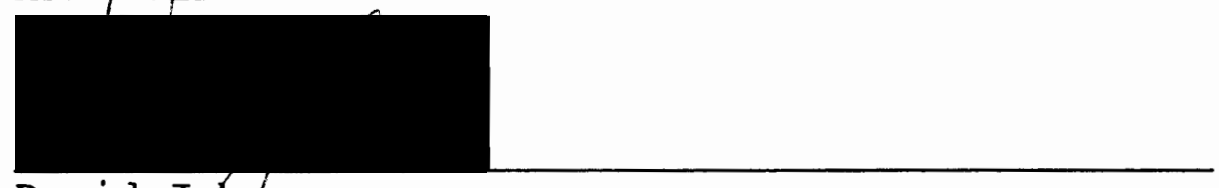

David Johnison,

Chair Department of History

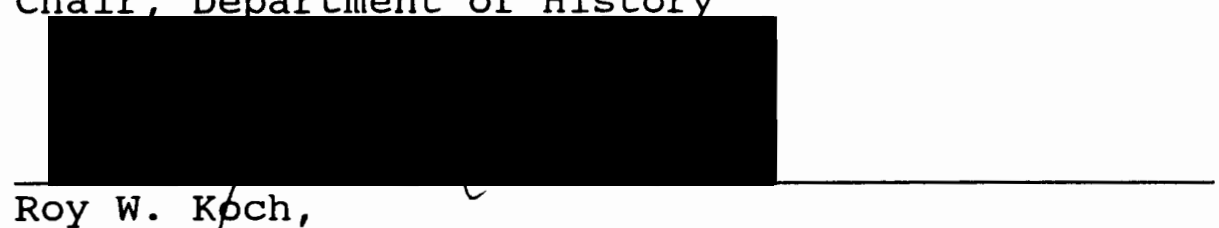

Vice Provost for Graduate studies and Research 


\section{TABLE OF CONTENTS}

I LEGAL BEGINNINGS, 1787-1795 • • • • • • • • • • 1

II THE MANNING PROBLEM • • . . . . . . . . . . 15

III THE AMERICAN RESPONSE . . . . . . . . . . . 22

IV ANTHONY MERRY AND JAMES MONROE . . . . . . . . 36

V THE TREATY OF 1806 . . . . . . . . . . . . . 46

VI THE CHESAPEAKE-LEOPARD ENCOUNTER . . . . . . 62

VII IMPRESSMENT TAKES A BACK SEAT, 1807-1812 • • 74

VIII EPILOGUE, 1812-1818 • • • . . . . . . . . 86

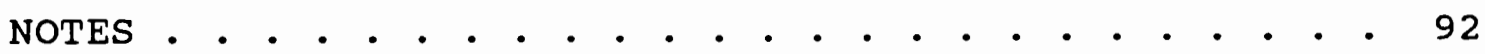

WORKS CITED . . . . . . . . . . . . . . . . . . 115 


\section{CHAPTER I}

LEGAL BEGINNINGS, 1787-1795

In the years following United states independence, maritime concerns dominated the young nation's relations with Great Britain. As they vied in the commercial arena, questions of the carrying trade and neutral rights helped push the two countries apart. Yet nothing, it seems, was quite as divisive as the problem of impressment. Impressment, as it was called, was the primary method Great Britain had for staffing its navy. In this early non-democratic form of the draft men were simply snatched up and forced into service on British ships of war. American citizens were often mistakenly taken in these roundups due to similarities between the nationalities and a lack of adequate proofs of American citizenship. At first a seemingly innocuous difficulty, the problem persisted through the terms of four American presidents, defying resolution, heightening other antagonisms and eventually leading to war.

This thesis provides a narrative of the impressment dispute from its origins in 1787 to its somewhat inconclusive resolution in 1818. James Zimmerman addressed the issue in Impressment of American Seamen, published in 
1912. Yet Zimmerman overrated the importance of impressment as a factor in international relations while disregarding issues relating to boundaries and payments on loans made before the war. Zimmerman also ignored the British side of the controversy. This thesis will show that both America and Britain shared responsibility for the emerging controversy. The combination of a large British navy and a growing American merchant force made the impressment dilemma a virtual certainty.

Impressment as a method of staffing the Royal Navy went back so far even the British had no idea of its origins. In 1771, Sir William Blackstone, of His Majesty's legal force, spoke of the "right" as existing in less than certain terms:

It hath very clearly...been shewn by sir Michael Foster, that the practice of impressing... is of very antient date, and hath been uniformly continued by a regular series of precedents to the present time...The difficulty arises...that no statute has expressly declared this power to be in the crown... This method of impressing... is only defensible from public necessity, to which all private considerations must give way.'

The main legal standing for impressment rested upon the fact that it had been done as long as anyone could remember and remained the only adequate method for staffing the Royal Navy.

By the time Blackstone wrote his commentaries on the Laws of England during the mid-eighteenth century, impressment had fallen out of favor in Britain. The Lords 
of the Admiralty themselves were "as much averse to the present method of pressing as any man can be, and wish some better method was established to man His Majesty's ships."2 Blackstone documented this general feeling. "The power of impressing men," he wrote, "has been a matter of some dispute, and submitted to with great reluctance." 3

Despite such reluctance, impressment continued. The British government tended to be very strict about its sailors, holding tight to the men who constituted its navy. There was no recognition of a subject's right to change his allegiance. Blackstone emphatically supported this view. "An Englishman who removes to France, or to China," he wrote,

owes the same allegiance to the King of England there as at home...For it is a principle of universal law, that the natural born subject of one prince cannot by an act of his own- no, not by swearing allegiance to another-put off or discharge his natural allegiance to the former. ${ }^{4}$

This was, in effect, the closing of a loophole. No matter how far flung the British Empire, no British sailor was going to weasel out of service to the crown.

Using this logic, the British government at first refused to accept that American independence freed British seamen who had lived in America prior to 1783. At the same time the British Navigation Act required that both the master and three-quarters of his crew be the same 
nationality as the ship they sailed on. By 1788 British officials began to combine these facts to their advantage:

Edward Burrow, the customs officer at Glasgow, reported... that he had seized the American Ship Jenny, guilty of a sensational list of infractions, including the composition of her crew: seven Americans and four Britons...Henry Wilckens, of that city, told [Lord] Hawkesbury [President of the Board of Trade], early in 1790...that four American vessels had recently called at London and had remained unmolested there although the master and "every man on board" was British."

Clearly the Admiralty, as much "against" impressment as they were, felt themselves literally surrounded by deserters simply begging to be pressed back into service. This was an attitude that was bound to be troublesome.

The diplomatic controversy began in 1787 when English captains, preparing for war with France, began impressing sailors who claimed to be American. Andre Limozin, an American minister stationed in France, wrote to Secretary of State Thomas Jefferson in September that "[w]e have been informed yesterday...that there is now a general press for the Sailors thro all England." 6 And by mid-october he could relate the specific instance of a British tobacco ship that had just arrived from virginia:

The ship has an American crew, or so they declare under oath...but the master, hearing that all British officers are called home, intends to proceed to London and threatens when in Liquor (which case happens to be often) to deliver the whole crew on board British men of war. ${ }^{7}$ 
Such narrations illustrated how easy it was for an American, seemingly indistinguishable from a subject of the Crown, to end up serving on a British ship of war. Jefferson promptly instructed Limozin to protect American sailors "against being carried against their will to England, where they will certainly be impressed to serve against France, and, if taken prisoner by the latter, may perhaps be hung as pyrates." 8 Again, Jefferson showed the peril of these sailors who, once forced against their will to fight for England, could then be hanged as war criminals by France. What he did not address was the general ineffectuality of the American envoys in securing the release of wrongly impressed men.

By the time Jefferson's message arrived the danger of war between France and Britain had blown over. Still, the pattern was set. In fact, the incident Limozin spoke of was an almost classic example of the impressments to come. First there would be an instance of arbitrary British impressment, usually by an irascible and dictatorial British captain. Then the pressed sailors claimed with little or no proof that they were American. After an ineffectual response from the American government which left the greater question of impressment unresolved, a beleaguered American official in a foreign port would "demand" the sailors release. The sailors would, of course, not be released, or at least not for some time. 
This pattern recurred again and again throughout the twenty-five or so years of the impressment controversy.

In early 1790, war between France and Britain loomed once more on the horizon and retired Senator John Rutledge wrote Jefferson from London that "three thousand seamen had been pressed the night before." 9 This was not as astounding as it sounds. The press gangs often operated in such sweeps. However, many of the pressed were American, or claimed to be, and Rutledge soon ran up against what was to become the recurring problem of inadequate proof of American citizenship. "In general, the press officers have objected to the proofs offered of [our sailors] being Americans." Rutledge wrote, adding that he hoped merchants would convince their captains to obtain proper citizenship papers for their sailors. ${ }^{10}$

The very question of such certificates was to become a key stumbling block to the resolution of impressment. In the years to come, America would offer detailed refusals of the plan. At this point Rutledge's advice was simply ignored, thereby allowing the impressments to go on unhindered. "A merchant of Boston," wrote William Short, the american minister to France, "assured me there had been more than three hundred American sailors impressed into the British service."11 American consuls Nathaniel Barrett and David Humphreys concurred. Barrett wrote, "Every vessel which arrives is subject to the Inconvenience of having her 
men taken out and in many instances conveyed out of the way of redress." 12

Humphreys voiced even stronger concern. "No vessel arrives from any Port that is not entirely stript of its Crew by the Press Gangs." 13

It was easy to get worked up over the problem as not only was the fate of the sailors horrendous but the impressments themselves were relentless. The somewhat frenzied response of the American consuls would be repeated by other Americans on both sides of the Atlantic in years to come.

The Foreign office and the Admiralty responded to such charges by arguing that it was almost impossible to tell an American sailor from a British counterpart. Jefferson's informant in London, John Brown Cutting, wrote to the Secretary of state in July of 1790 telling of his attempts to discuss the matter. "I was told there was much difficulty in discriminating an American from a British seaman: that many British attempted to pass for Americans."14 Finally, in November, consul Joshua Johnson informed Jefferson about his talks:

I have had some conversation with the Duke of Leeds' Secretary... on the subject of what Constitutes an American Subject, and that of an English one; his answer was that the similarity of manners, language etc. put it out of the power of Government to discriminate. ${ }^{15}$ 
This similarity was separately noted by others. George Hammond, first British minister to America, wrote to President Washington, warning that "[t]he practice in Great Britain of impressing seamen whenever war is apprehended, will fall more heavily on yours than... any foreign nation, on account of the similarity of language."16 Confusion between the nationalities was compounded by the fact that British sailors wishing to escape military service often obtained faulty American citizenship papers and then signed on board United States' merchant ships. Even as late as 1794 Lord Grenville, the British Foreign secretary, could complain to John Jay that, "Such cases have occasionally arisen...especially where there so often exists an interest and intention to deceive." 17 Though there were many reasons for British sailors to sign on to American trade vessels, safety was a prime motive.

The British seaman's bent toward desertion was encouraged by many Americans. The carrying trade between the West Indies and Europe was primarily in American hands, a development which drew large numbers of British sailors into the American merchant service. British seamen were urged to desert by American merchants in every port in the states. In fact, every British Government packet which entered New York harbor during the winter of 1801 lost almost its entire crew. These deserters easily obtained fake citizenship papers. ${ }^{18}$ 
The official American line on persuasion to desert was quite different. Thomas Jefferson claimed, "You ask, what encouragements are given to emigrants by the several states? No other than a permission to become citizens." However, even Jefferson had to admit that the rules for granting citizenship were "not uniform" in the United States. ${ }^{19}$ In 1790, Lord Hawkesbury voiced his anger over what he termed American "nurseries of seamen" although he felt that "this evil is also without remedy."20 And in 1794, after the start of the Anglo-French War, George Hammond admitted that America used "every artifice...to induce British seamen to desert from the ships on which they arrive."21 Although these accounts are somewhat exaggerated there can be no doubt that Americans were vigorously involved in the attempt to encourage desertion. Such behavior undoubtedly led to bad feelings in the British Admiralty and contributed to various delays and evasions in the release of wrongly impressed men. Still, impressment was not yet a foreground issue. With no truly serious incident to get excited about, the American government remained calm, merely making a few less than strenuous efforts to limit the practice. The only people truly concerned seemed to be American consuls who spent a large portion of their time in the attempt to free American sailors. It was these men who stressed the need for certificates of citizenship as a prevention from 
impressment. Joshua Johnson wrote to Jefferson telling of his plan to give out a general protection to every American citizen on the back of their shipping articles. ${ }^{22}$ Their advice was ignored at best, disagreed with at worst. In July of 1792, Jefferson ordered American minister to Britain Thomas Pinckney to open talks on impressment. Jefferson had rejected the idea of requiring American sailors to carry proof of citizenship feeling it would weaken their legal standing:

We entirely reject...that our seamen should always carry about them certificates of their citizenship. This is a condition never yet submitted to by any nation... [Through the] loss of this paper evidence...the British government would be armed with legal authority to impress the whole of our seamen. ${ }^{23}$

This argument would dominate American relations with Britain for the next generation, though whether Jefferson worried about the loss of citizenship papers or the loss of much needed British sailors is not clear.

Pinckney met with Lord Grenville to deliver Jefferson's plan. "I then proposed to him the plan which you suggested of letting the Vessels protect a certain number of men according to their tonnage." specifically, America was willing to let British officers check the number of men on United States ships as long as no press gangs would come aboard unless there were more men than the listed amount. Naturally, this was unacceptable:

He said the obvious objection to this proposal 
was that in case of war with any other nation

[American] vessels would afford such protection

to [British] sailors as would induce them to

crowd into our Vessels to the manifest injury

both of their royal navy and merchant service. ${ }^{24}$

The British government insisted that the number of sailors on board a ship had very little to do with the number of British sailors it carried. It could ill afford to let American vessels pass unmolested simply because their crew was listed as thirty men and that was how many were there. Despite the complaints of America's foreign ministers, at this point impressment was far from the head of the list when it came to Anglo-American discord. on March 5, 1794 Jefferson's successor as Secretary of State, Edmund Randolph, gave Congress a report on foreign aggressions against American commerce. Though impressment was mentioned it was only one of several anti-British charges, all of which were given a corresponding French grievance. ${ }^{25}$

The lack of interest in the topic is further demonstrated by the response in the House of Representatives to a bill to protect American sailors. Issued in the spring of 1794, the bill moved to "enable American seamen to obtain and carry evidence of citizenship, for the purpose of protecting them from impressment into foreign service."26 It was the infamous proof of citizenship that Jefferson had already turned down. After a month, the bill was debated. "Mr. Fitzsimmons was against the bill...because every man... who 
has not a certificate, will, in future, if the law takes place, be considered as not American."27 A suspiciously Jeffersonian statement. Murray defended his bill, "It was not his intention," he said, "to promise a complete system in this desirable point. His wish was rather to secure the advantages which certainly were within our reach."

Whatever the advantages were to Murray's admittedly incomplete plan they were undoubtedly less than apparent. The bill was voted down the same day. ${ }^{28}$

Only America's foreign officials were inclined to treat the problem as if it had any need to be resolved. John Jay was in Britain at the time working on the Treaty of Amity, Commerce and Navigation. Though his instructions contained nothing on impressment he broached the topic anyway. On July 23, 1794, Jay tried to pressure Lord Grenville into giving on impressment rather than have negative public opinion in America jeopardize their treaty negotiations:

The cases of captures transmitted to me are numerous... It appears to me unfortunate that the vessels lately sailed from hence to America carry with them discontents on account of Americans impressed and detained. Those discontents will naturally add to the impressions made by masters of vessels and others daily returning from the West Indies, and publishing details of the severities which they there experienced. ${ }^{30}$

Soon after, on July 30, Jay again expressed the hope, "that [impressed] Americans...be immediately liberated, and that 
persons...with His Majesty's commissions do, in future, abstain from similar violences." ${ }^{31}$

Grenville agreed that wrongful impressment was unfortunate but stopped short of throwing out the traditional method Britain had of manning its navy:

On the subject of the impress... if...American seamen have been impressed... it has been contrary to the King's desire... With respect to the desire expressed by $\mathrm{Mr}$. Jay that new orders might be given with a view to prevent... [wrongful impressment], Lord Grenville has...obtained His Majesty's permission to assure Mr. Jay, that instructions, to the effect desired, will be renewed..$^{32}$

In other words, nothing was going to happen. The only headway Jay made was to get Grenville to finally agree that those resident in America at the moment of independence were American citizens:

I do not think one instance can be brought where a seaman has not been discharged, who could produce... any probable...ground for supposing him a native citizen of the U.S., or a resident there at the time of the separation from [Great Britain]..$^{33}$

There were however, numerous incidents of American sailors who had died in the service of the Royal Navy while engaged in years-long battles to regain their freedom.

Paradoxically, as the other issues in Anglo-American relations reached a settlement, impressment began to worsen. In November of 1794 Jay and Grenville signed the Treaty of Amity, Commerce and Navigation and the two countries were placed on a more amicable basis than ever. 
Just weeks later the Royal Navy would again need a surplus of men for the just renewed war with France. Impressment would increase dramatically, and jump to the forefront of United states-British diplomacy. 
CHAPTER II

THE MANNING PROBLEM

The dispute over impressment was caused by an acute shortage of sailors. There simply were not enough trained and able-bodied seamen to staff both the growing American merchant fleet and the British royal navy while it was at war with France. Beyond this shortage the royal Navy faced a further obstacle. The Navigation Act stipulated that every British merchant ship maintain a staff that was at least three-quarters British. ${ }^{1}$ Though Parliament reduced the percentage to one-quarter for the duration of the war there still weren't enough sailors. ${ }^{2}$ By end of the eighteenth century the British navy was twice as large as it had been fifty years before. There were approximately 250 ships in service in 1700, this number had risen to just over 500 by the year $1790 .^{3}$

The type of man who could be pressed was strictly regulated. So-called "landmen" were ineligible. In 1776, Lord Mansfield, the Chief Justice, had ruled:

Persons liable must come purely within the description of seamen...He... who is not within the description does not come within the usage. The commission is not to impress landmen. ${ }^{4}$ 
Which was about as clear as it got. To top off the Admiralty's problems, the practice was decidedly unpopular, both abroad and at home.

originally the term "gang" meant a group of sailors assigned to a specific task. The activities of the press gangs gave the word the negative and violent connotations it carries today. The violence, however, was not always perpetrated by the gangs themselves. In the absence of any real police force press gangs often found themselves subject to verbal and physical harassment. In 1803 one captain told of how his gang of men, "were attacked by large mobs, principally women, who by throwing things hurt several officers and rescued several men."

Another officer in charge of a press gang wrote: On one occasion I was assaulted by a shower of brickbats: on another, a volley of either musket or pistol balls was fired into my room one evening as I was reading at my table. ${ }^{6}$

Clearly, British subjects may have loved their King, but they hated his press gangs. Because of the hardships associated with pressing on land the gangs often found it easier to do their work at sea. In 1795 the Admiralty had a force of 528 sailors at Dover just for this purpose. 7 While Britain's navy suffered under this lack of sailors the government continued to receive reports of British sailors aboard "divers Foreign ships." 8 something 
had to be done. Early in April, 1795 an order in Council put an embargo on all foreign ships in British ports. 9

On receiving the Order, Admiral William Parker, commander of the undermanned Jamaica Station, insisted all foreign ships be:

thoroughly examined...particularly Americans, for the purpose of detecting English Seamen that may be concealed on board... you are to cause them to be taken out, as also such as have not certificates of Citizenship. ${ }^{10}$

This would seem to be a rather transparent ploy for the quick acquisition of as many able-bodies seamen as Parker could lay his hands on. The Admiral's need for these men was mostly due to deaths among his own sailors from disease, a problem for which Jamaica station was infamous. In 1745 the Admiralty had punished one commander for "letting his Men know the service he was going in, which resulted in total desertion." "The Admiral's anti-American prejudice is a different question. It seems likely to have come from a combination of actual experience of American 'recruitment' efforts and reports from the home office.

In defense the United States government charged that short-handed British officers would deliberately impress Americans. Secretary of state James Madison wrote angrily to Rufus king:

The complaints daily arriving at this office show that our mariners are impressed without the least respect for their legal protections, certified in the most authentic forms... It cannot be pleaded that the seamen in question were taken 
in vessels where they had entered voluntarily...These wrongs have made a deep impression on the American mind. ${ }^{12}$

However, what Madison referred to as "authentic" forms of certification were often the most woefully inadequate and poorly documented of "proofs".

The British government vigorously denied deliberate impressment, stating that they had no desire "to acquire American seamen." England's object was the "much broader and more important one of guarding herself from being deprived of her own."13 However, only rarely did an abusive British officer to get so much as a scolding.

The Anglo-French War eventually drew in Holland and Spain as well leaving most of the European colonial trade in American hands. Three years before the war, American ships carried 59 percent of the nation's foreign trade. By 1795 the proportion had increased to 90 percent. ${ }^{14}$ American shipping could only expand this dramatically through the liberal use of foreign sailors. Thus, America's refusal, indeed inability, to cease in the employment of British sailors contributed substantially to the dispute. Increased demand for sailors caused the British to raise the pay of their seamen to lure deserters back. ${ }^{\text {is }}$ The United states was not oblivious to the economic threat to the well-being of its merchant fleet. Joshua Johnson wrote to Thomas Jefferson: 
It has occurred to me that granting Protection to individuals, they may make use of them to the prejudice of the Navigation and commerce of our country, by entering in the service of those, who will pay the highest Wages, the English now give Three pounds five shillings sterling per Month, while the Americans only give thirty-six Shillings. ${ }^{16}$

Here was yet another reason not to give sailors protections. A protected sailor was a safe sailor, in effect, a free agent able to work for whom he chose. Such arrangements appeared to threaten American maritime interests.

Consul William Knox also saw the inherent economic danger and wrote to Jefferson from Dublin:

It is an object of great consequence to American commerce for regulation between the United states and England determining American citizenship exclusive of birth. ${ }^{17}$

Knox expressed a sentiment typical of America's foreign ministers, the desire for adequate proofs of citizenship. Typically, he was ignored.

The pay on British merchant vessels also rose at this time. While wages in the $1740^{\prime}$ s were rarely more than forty-two shillings, during the war they rose as high as sixty shillings per month. ${ }^{18}$ Britain still found herself short of sailors. It would seem then, with pay being so much higher in the British navy, that the real attraction was absconding from military service. Though British merchant ships paid more than their American counterparts they were also based in England. This proximity to the 
home country undoubtedly made a man's chances of impressment appreciably greater. Once a man was impressed he was placed on a war ship and taken to battle which was a dangerous and uncertain way to make a living. Though the pay was more, you had to be alive in order to spend it. Early in 1807, Secretary of the Treasury Albert Gallatin conducted a study to see if America could afford to stop using British sailors. He found that half the seamen on United States vessels were British. Americans "recruited 2,500 British sailors every year."19 Jefferson replied, "Your estimate of the number of foreign seamen in our employ, renders it prudent...to drop the idea of any proposition not to employ them."20

Indeed, America never did stop in her efforts to entice British sailors into service on her merchant vessels. British officials reported in later years that nearly every British war ship that landed in America lost part of her crew. Admiral sir Hyde Parker, commanding the Jamaica station from 1796 to 1801 , claimed it was "perfectly well known to us that two-thirds of the seamen that Navigate the American Trade are... English seamen."21 Any officer who felt this way, and many seemed to, was unlikely to give a sailor with inadequate proof of citizenship the benefit of the doubt.

The British government was arbitrary in their use of the impressment system. If even British subjects were 
enraged by the practice it seems only natural that Americans would be all the more upset. They were. Yet the Admiralty continued on with impressments, justifying them as the only way to man the all-important royal navy.

The American government also carried its share of the blame. By refusing to stop the corrupt and illegal methods by which British sailors magically became American citizens the United States government appeared to support, and off the record did support those actions. 
THE AMERICAN RESPONSE

Just as no British government ever seriously considered stopping impressment, no United states administration ever admitted to Britain's right to impress on the high seas. American arguments came from different angles but always agreed that the practice was unacceptable.

President John Adams denied Britain's right because of the complete absence of any such right in writings on the law of nations:

There is no principle under heaven, by which they can justify taking by force...even a deserter from their own army or navy...the thing has absolutely no principle. ${ }^{1}$

This was notwithstanding the British 'legal' defense previously discussed. While this defense is rather shaky it apparently worked for the Admiralty.

Thomas Jefferson believed that a merchant vessel was part of the territory of a sovereign state, though he never made his beliefs official.

I write this, too...that it may not be considered as official, but merely my individual opinion... On an element which nature has not subjected to the jurisdiction of any particular nation... it would seem that the particular portion...occupied by the vessel of any nation.... is for the moment, the 
exclusive property of that nation, and with the vessel, is exempt from intrusion by any other. ${ }^{2}$

Jefferson was thus claiming the high seas to be the sovereign territory of any ship traveling on them at a given moment. Under this somewhat radical view, to board a United states merchant ship on the high seas would be the equivalent of an invasion of American territory. An act of war.

News of increased impressments reached America at the same time debate began in the senate on Jay's Treaty. The two issues quickly became intertwined. Anti-treaty forces latched on to impressment, loudly decrying the lack of a section in the treaty against the practice. This, they said, was reason enough not to ratify the agreement. ${ }^{3}$

Jay warned "the forming of any very satisfactory arrangement" on impressment would "prove an arduous task"4 but, probably due to his personal feelings on the subject, he recommended the attempt be made. The focus on impressment as a tool to fight the treaty brought the issue to many people's attention for the first time. The result was a flurry of Congressional activity. Edward Livingston, an opponent of the treaty, suggested on February 19, 1796, that the House appoint a committee:

To enquire... whether any and what Legislative provision is necessary for the relief of such American seamen as may have been impressed" and "to report a mode of furnishing American seamen with such evidence of their citizenship as may protect them from foreign impressment. 
Such a committee was formed and on February 25 recommended:

A plan to afford [impressed sailors] relief, the principle part of which is that two agents shall be appointed by the United States, one to be sent over to England and the other to the West Indies...to release such as they are able... and learn the number of citizens who have been illegally seized. ${ }^{6}$

With the new interest in impressment it was now necessary not just to fight the impressments but also to accurately determine just how bad the problem was.

On March 1 the resolution carried. ${ }^{7}$ The first Act for the Relief and Protection of American Seamen was the result. The act came to a vote in the House of Representatives on March 28, 1796. As the act's chief proponent, Congressman Livingston declared "there could be no doubt that American seamen had been impressed and very grossly abused." Thus the act was sorely needed. It was hard to argue with such basic logic. After Livingston's lengthy speech "the question was decided in the affirmative- yeas 77 , nays $13 . " 8$

In an attempt to halt the problem entirely the act included a list of proofs required to establish a man as an American citizen. "The certificates which would be issued would be descriptive of the kind of citizenship of its possessor."9 These descriptions were dropped by a joint House-Senate committee.

Instead of having certificates issued to three descriptions of American citizens, viz: natives, foreigners who were in this country in 1783, and 
those who have obtained their citizenship since, they are all to be included under the head of American citizens. ${ }^{10}$

These, however, were the kind of distinctions Britain required, so the certificates called for were to be no real protection at all.

Blissfully unaware of this, the senate began consideration the next day. By April 19 the senate had a bill they liked, but not the one that had passed the House. Rather than making a strong statement in favor of United states sovereignty and neutral rights they simply said it was "the duty of the master of every ship... of the united States, any of the crew whereof shall have been impressed... immediately to make a protest." 11 As if masters of ships typically would not make a protest while their sailors were hustled away. The watered down bill, which also eliminated all mention of proofs of citizenship, passed the Senate on April 20.12 Not surprisingly, this useless act did not suffice to quiet the House. On May 28:

The Speaker laid before the House a letter which he had received from ten American captains, now... at Jamaica complaining of the illegal impressment of their seamen by British ships of war... They pray for the interference of Government. ${ }^{13}$

No interference was forthcoming, but the incident did serve to keep the topic of impressment fresh in the congressmen's minds.

A few months later Congressman William Vans Murray moved to amend the existing act to require seamen to 
produce a birth or baptismal record from their home along with the testimony of a witness. One of the specifically stated reasons for this revision of the act was:

Two clauses had been omitted in the bill for the protection... of American Seamen. They were the clauses respecting certificates, on which the two Houses had differed in opinion. ${ }^{14}$

This was perhaps the only attempt at setting guidelines for American citizenship papers that met with no opposition. Quite the opposite. On March 1, 1797 an attempt was made to make the requirements for American citizenship even stricter.

Mr. Harper spoke at considerable length against the mode laid down for the ascertaining of citizenship, which was to be proved... by one credible witness. Mr. Harper proposed that the testimony of three freeholders should be necessary.

This proved to be too much even for the House where the proposal was immediately negatived, garnering a mere three votes. ${ }^{15}$ Though the House passed the amendment on March 2, 1797, the senate put off any action until the next session effectively tabling the bill. ${ }^{16}$

At this time Rufus King was sent to Britain as America's new minister. Secretary of state Madison's initial instructions refrained from asking him to strongly protest impressment. Privately, Madison claimed to be satisfied with Anglo-American relations. "The present policy of the British government treats the United states with more respect and conciliation than heretofore." 17 
Nevertheless, on August 10, King, newly arrived in London, told Lord Grenville that America wanted to renew talks about impressment. His government "thought after fair reflection...that we were entitled to pass the high seas without interruption."18

Grenville replied that he would have to discuss it with the First Lord of the Admiralty before he could speak on the topic. This was undoubtedly because of the ever growing evidence that United states officials would sell citizenship to anyone who could afford it. In the House of Commons it was announced:

In... New York...the collector one day allowed an old woman to qualify a whole host of seamen... by swearing that she knew they were American citizens... The very clerk remonstrated against [the transaction's] baseness... The reply of the collector was that it was no business of his... and the old woman continued during the whole of the day to receive her two dollars for every oath that she took... In Philadelphia occurrences of a similar nature had taken place. ${ }^{19}$

Instances of such flagrant abuses were far from rare in America's headlong rush to gather the sailors of the world into her merchant fleet. Because of such behavior Britain felt justified in using whatever means necessary to regain their lost sailors. The British government armed Grenville with a report from the law office to the effect that a belligerent was entitled to remove his own subjects from on board a neutral vessel. ${ }^{20}$ The battle was joined again. 
As a senator, King had always had his doubts about the efficacy of the American system of citizenship proofs. Now he found his reservations justified. ${ }^{21}$ The British, predictably, put little stock in these easily obtainable certificates. Lord Grenville asked King to tell the American consuls in Britain that they were exceeding their authority by issuing them.

I have considered the proposals, contained in your letter...It seems scarcely possible for the King's government to accede to any arrangement grounded on such a basis, without risking the total sacrifice of that on which depends the whole maritime force of Great Britain. ${ }^{22}$

The American certificates were thus felt to be too weak for Britain to even consider using them as a basis for limiting impressment.

King complied with Grenville's request, holding out the vain hope that congress might toughen its useless law. He wrote to Jonathan Dayton, Speaker of the House, a month after he'd heard from Grenville.

I must request you to consider... the provisions of the act of congress... respecting the certificates of citizenship... The act does not in any manner specify the nature of the proof on which these certificates are to be granted... It is not required by the law... that the certificate should distinguish... the grounds upon which it is granted. ${ }^{23}$

His request was not considered and the problem then went on for some time with consuls continuing to issue their worthless protections which Britain continued to ignore. 
In August, 1797, Grenville dogmatically stated that certificates issued by United states consuls would not "be considered... as affording any evidence of the birth or Citizenship of the persons exhibiting them."24 Even this had little effect. As late as 1806, Thomas Jefferson could write to Madison:

I think it would be proper to send to [the collectors] a copy of the papers respectively concerning them... as to admonish them to be scrupulously exact in their issuing certificates of citizenship, as the contrary conduct disgraces us. ${ }^{25}$

Which was an interesting comment since the "disgrace" had by then been going on for some ten years.

Congressman Livingston, a hard man to keep quiet on the subject, made a final attempt to solve the protections difficulty. In December of 1797 he reminded the House of William Vans Murray's attempt to amend the Act for the Protection of American Seamen:

That a bill passed the House in February last, for the relief and protection of American Seamen, but not being acted upon by the senate, he found it would be necessary to bring forward the business anew in the House. ${ }^{26}$

Which he proceeded to do in a most unique manner. Livingston attempted to make captains financially responsible for their crew. His amendment required "masters of vessels to give bond to bring back, or give a due account of all the sailors they take out on their voyages." This sort of amendment was bad for business and 
thus bound to be unpopular. Consideration was postponed because of various objections and after February, 1798 the amendment was never discussed again. ${ }^{27}$ In fact, the entire matter idled for most of the rest of the year until an incident at Cuba again excited interest.

On December 31, 1798, Congressman Harrison otis introduced into the House:

a report... relative to the impressment of a number of American seamen from a vessel of war of the United States [the Baltimore] into an armed ship of Great Britain.

It was a case similar to the impressments in the west Indies which had first brought impressment to the attention of congress. Now the new announcement had a similar effect. The House immediately request ed the President send them any pertinent information on this case. ${ }^{28}$ BY January 8, 1799, Congress received a letter sent to the Secretary of State by George Morton, U.S. consul at Havana "of the partial capture of an American fleet under the convoy of the Baltimore sloop-of-war." Morton included a letter from Lewis Trezevant and William Timmons who witnessed the incident, though they were not on board the Baltimore.

Captain Philitps... informed us that...the Commodore had told him that he should take out of the Baltimore all such men as had not American protections... he had remonstrated against [the Commodore]... as not even those who were really Americans...could show protections, because it was always thought that our flag, on board of a Government ship, was a sufficient protection. 
of course, it was not, and the captain must have known it. In the end fifty-five men were removed from the Baltimore, though all but five were returned. ${ }^{29}$

When the facts were known the case seemed less substantial and appears to have had scant impact. congress did pass a new version of the protection Act in February, 1799 and the Senate approved it in March. ${ }^{30}$ Unfortunately the only revision was a request that the secretary of state submit an annual report on impressments. ${ }^{31}$

At the same time, Rufus King had finally had enough of Lord Grenville's evasions. Discouraged, he wrote to Secretary of state Timothy Pickering in July:

I have attempted again and again... without success to convince this Government that both Justice and a friendly Policy required of them to agree with us in a convention...that should at the same time give to them as well as to us adequate and reasonable security in regard to our respective Interests... I have ceased to urge it from a full persuasion that my Exertions would be fruitiess. ${ }^{32}$

Despite these words from their own envoy it is apparent that the American government was as unconcerned as the British. Not until December 12,1800 was the subject again broached in the Senate.

The Vice-president laid before the senate a report from the secretary... of state, in pursuance of the 'Act to revive and continue in force certain parts of the act for the relief and protection of American seamen'... and the report was read, and ordered to lie for consideration. ${ }^{33}$

No such act was passed. 
The Peace of Amiens in 1801 ended British-French aggression and pushed impressment even farther into the background. However, United states agents in Great Britain had unexpected difficulties obtaining the release of captured sailors. One such agent, David Lenox, wrote to Secretary of state Madison in March, 1802. "I had, with you, anticipated the discharge of all seamen claiming protection as American citizens, on peace taking place... In this I have been disappointed."34 Though Britain now had no immediate need of the impressed sailors the government could not afford to relax their stance on the impressment issue. Lenox wrote to Even Nepean of the Admiralty Office: I...send you...a list of 558 seamen, representing themselves to be citizens of the United states of America and detained on board His...Majesty's fleets, for whose discharge I made applications... and to which answers were returned stating that, having no documents to prove their citizenship, the Lords Commissioners of the Admiralty could not consent to their discharge. ${ }^{35}$

The Admiralty could not release a sailor who had no proof of citizenship simply on the basis that he claimed to be American. Not if they wanted to maintain any degree of consistency at all.

William Marsden attempted to explain the matter to Lenox three days later:

The admission of the principle that a man declaring himself to belong to a foreign state should, upon that assertation merely...be suffered to leave the service, would be productive of the most dangerous consequences to $\mathrm{His}$ Majesty's navy. ${ }^{36}$ 
Britain's dilemma is clear. Marsden was right that just saying you were American was hardly enough. Deserters were doing that already.

in retrospect it was probably for the best that Britain kept her acquisitions. War broke out again in may, 1803. By July American newspapers were full of reports of renewed impressments. The Philadelphia Aurora demanded Britain "should frankly and perfectly respect the neutrality of the United States."37 Boston's Independent Chronicle called for America "to take a stand, as it respects our neutral situation." 38 And the Salem Register warned that British impressments could "arouse the indignation of the American people." 39 If the papers were any judge, the American public was becoming fed up with the British practice.

In May, 1803, Rufus King made his final attempt to halt high seas impressments. Admiral st. Vincent, First Lord of the Admiralty, even agreed to the terms of a convention, before quickly backing out. He excused himself to king by saying that he could not agree because the proposed ban on impressments covered the narrow seas [the English Channel and the Irish Sea] which Britain considered territorial waters. ${ }^{40}$ King left England on May 21, 1803, defeated, though he later believed he might have been successful if he'd stayed in England longer. ${ }^{41}$ 
Though the situation was rapidly growing worse President Jefferson's administration attempted to maintain calm. Jefferson announced in october that America's goal was "to cultivate the friendship of the belligerent nations." ${ }^{42}$ Public outrage made it hard for his administration to act cautiously. Jefferson decided to take as official U.S. policy the points King had managed to get unofficial agreement on.

On the subject of our seamen, as both parties were agreed against impressments at sea, and concealments in port, I suppose we may practice on those two articles as things understood, alth'o no convention was signed. ${ }^{43}$

Aside from the fact that it is useless to try to force a country to adhere to unofficial agreements, the British had never agreed against impressments at sea. They merely stated that they were not deliberately impressing American citizens.

In an attempt to prevent any incidents from developing Madison sent instructions to King's replacement, James Monroe in october. He insisted naval officers "abstain" from impressments. ${ }^{44}$ Regrettably, Great Britain was in no position to stop the practice. Desertions rose in frequency yet again. In late November the House of commons was busy discussing a "bill for preventing the desertion of guilty officers and seamen."45 This bill passed on March 9, 1804 and included a provision "for punishing mutiny and desertion" as well as one "for allowing vessels...charting 
out from any port in Great Britain to complete their full number of men at certain ports for the present."46 since laws are generally not passed without a reason it seems safe to extrapolate that England was experiencing its fair share of desertions, was in need of sailors and was not too picky about where she got them.

In August, Madison gave Monroe instructions for new talks on impressment. If Britain would agree that the United states flag gave protection to those traveling under it, America would promise unconditional surrender of all deserters. ${ }^{47}$ But Madison was also told to wait. The Jefferson administration had placed itself in a cautious holding pattern until the arrival of the new British minister to America, Anthony Merry. 
CHAPTER IV

\section{ANTHONY MERRY AND JAMES MONROE}

In late November, 1803 Anthony Merry arrived to become British Minister to the United States. Secretary of state Madison lost no time opening talks on the subject of impressment. Lord Hawkesbury, Grenville's successor, gave Merry no advice on the topic, instead ordering him to be a general good will messenger.

You will deliver to [the President]...His Majesty's sincere anxiety to promote and improve the Harmony and good Understanding which so happily subsist between His Majesty's Government and that of the United States.

Good advice, but unhelpful for the problems of the moment. During Merry's term as minister the issues of greatest concern were maritime, impressment one of the most important. From 1803 until the start of the war of 1812 just over 6,000 Americans were pressed into British service. ${ }^{2}$ Many Americans suspected the increase was meant to destroy America's growing merchant marine.

[Congressman] Crowninshield said that...he thought these impressments ought to be prevented... His intention was to prevent the American carrying trade to the West Indies from falling into the hands of other nations. ${ }^{3}$

In turn some British suspected American politicians were enlarging the issue for the sake of domestic political 
gains. As early as 1801, Edward Thornton, then British Minister at Washington, complained that despite peace between America and Britain desertion of seamen was encouraged in every United states port. He claimed this was a method used to keep British shipping out of American ports where it competed with United States shipping. ${ }^{4}$ Merry also distrusted American motives.

Dr. Franklin Jameson once said Merry served as minister "in pompous unhappiness." have been an accurate assessment. In his first dispatch to the Foreign office Merry reported that Madison had spoken of impressments three times. He also stated that he thought the American government was using the issue to get "a greater respect" for the American flag so they could gain "a more convenient system of neutral Navigation" than Britain had previously agreed to. ${ }^{6}$

While Madison and Merry discussed impressment Congress did as well. On November 22 the senate demanded "that the President...cause to be laid before the senate... information...relative to the... impressment of any seamen in the service of the United States" since the renewal of the Anglo-French War in May. ${ }^{7}$ On December 5, Madison reported that seventy men had been impressed, forty-three of whom were Americans. ${ }^{8}$ The actual numbers were far higher but this news was not received until March, 1804.9 The numbers were apparently high enough already. on 
December 12 the senate appointed a committee to study the need for further protective measures for American sailors. ${ }^{10}$ on January 14 this committee introduced a bill to close American ports to men guilty of impressment and to outlaw the loading or landing of cargo to or from ships of the offending nation. ${ }^{11}$

Merry was sure this was due to hostile anti-British sentiments in Jefferson's administration. He reported:

Instead of these steps having been produced by any general Sensation of the People...I...fear they have been produced solely by the unfriendly Disposition of the executive whose influence was so great in Congress. ${ }^{12}$

Merry was surely mistaken. Jefferson had already made it abundantly clear in his personal correspondence that his government was dedicated to a cautious policy of restraint. In March, 1801 he wrote to Thomas Paine:

Determined as we are to avoid... wasting the energies of our people in war and destruction, we shall avoid implicating ourselves with the powers of Europe, even in support of principles which we mean to pursue... we believe we can enforce those principles...by peaceable means.

This was a sentiment typical of Thomas Jefferson, a firm believer in the power of rational discourse. In october of the same year Jefferson again stressed his desire for peace in a letter to William short.

We have a perfect horror at everything like connecting ourselves with the politics of Europe... To be entangled with them would be a much greater evil than a temporary acquiescence in the false principles which have prevailed. Peace is our most important interest. ${ }^{13}$ 
If the President had been anti-British he would hardly have waited for Merry to arrive before making even the smallest move on impressment. Jefferson may have even had a hand in stopping passage of the bill as it was his close friend, Senator William Carey Nicholas who made an official announcement in late February.

"At no period of our government" had there existed "so cordial a friendship" between Great Britain and America. "Passage of the bill would disrupt the harmony" between them."14

The senate then postponed further discussion of the bill. Merry, however, was oblivious to the troubles incessant reports of impressments might be giving Jefferson and Madison. He was only concerned with the escalating number of British deserters. The Phaeton, which brought him to New York, had itself lost fourteen men. ${ }^{15}$ In April, 1804 he reported that twelve British vessels had been delayed at Norfolk because of desertions. Many of the former British sailors had apparently joined an American squadron going to the Mediterranean. Though merry complained to him personally Madison said that since the sailors had enlisted voluntarily there was nothing he could do. ${ }^{16}$

By June, 1804 Britain was again desperate for sailors.

The Secretary at War moved [in the House of Commons] for leave to bring in a bill to enable his Majesty to raise foreign corps, and indemnifying those who had taken foreigners into His Majesty's service. ${ }^{17}$ 
For the first time Britain was contemplating accepting the services of foreign sailors, mercenaries. The act passed on July 14, "enabling Subjects of Foreign States to enlist as soldier's in His Majesty's service."18

Two months later a British merchant vessel, the pitt, was boarded in New York harbor by a gang from the British ship Cambrian and fourteen British seamen were impressed. British consul Thomas Barclay was very much against such tactics as they violated American sovereignty. ${ }^{19}$ Typically, he was ignored.

Madison demanded the return of the men, an apology and the delivery of the officer responsible. Merry gave him nothing and referred everything to Lord Hawkesbury, who also did nothing. ${ }^{20}$ on August 15, Merry finally washed his hands of the matter entirely. He decided that the British captain had acted within his rights since a French ship had done much the same thing in Boston harbor several months earlier with no United States reaction. ${ }^{21}$ Madison called Merry "a mere Diplomatic pettifogger."22 But whether he was angry over Merry's accusation because it was true or false is difficult to ascertain.

After September, 1804 the State Department bypassed Merry completely, sending its complaints to the British government through the American minister in London. Results were achieved in November when Lord Harrowby, the Foreign Secretary, wrote to Merry: 
His Majesty's Government have perceived...the increasing Acrimony...by the American Secretary of State on the subject of the Impressment of seamen from on board of American Ships...strictest orders will be given without delay to the Commanders of His Majesty's Ships...to abstain from Impressments in the Ports of the United states. ${ }^{23}$

From now on Americans would only be impressed at sea. The British government's previous lack of response was due, in part, to other distractions. James Monroe had seen in April, 1804, that the Addington ministry would not survive attacks by Pitt on their running of the war. "While the late ministry was on the decline it seemed useless to press it on any concern of ours." ${ }^{24}$ In May Monroe's prediction came true and Pitt resumed control. Up until this point the situation had been as such: If a seized American could prove his birth Madison would send the documents to Monroe who sent them to the British Admiralty who ordered an enquiry. If by then the man wasn't dead from battle or disease or accident he would probably be released, after a year or two. ${ }^{25}$ Naturally this system was a pain to both the Admiralty and Monroe and probably accounted for Monroe's desire to see an end to the trouble.

In early June, Monroe approached the Earl of Harrowby about impressment. The new Foreign Secretary said he wasn't ready to act on it "nor did he know that he should be during the session of Parliament." 26 "The matter lay until August 4. On meeting with Harrowby to discuss Jay's 
Treaty, Monroe once more took the opportunity to discuss impressments. Harrowby claimed he had no desire "to encourage the expectation that there could be an agreement, nor entirely to preclude it." Monroe left, understandably less than enthused, concluding that the Foreign secretary "did not wish to encourage the expectation that we should agree in any arrangement on this head." 27

Finally, on september 1, after yet another meeting, Harrowby agreed to place the matter before the cabinet. ${ }^{28}$ They wasted no time. By september 20 , sir William scott from the High Court of the Admiralty, had informed Harrowby the American plan to stop high seas impressment was "unfit to be adapted."29 Monroe left for spain and the talks were suspended by "mutual consent." 30

Meanwhile, in late 1804 , Madison had again responded to a demand from the House of Representatives "that the Secretary of state...lay before this House a return of the number of...seamen who have been impressed." 31 The new numbers were now based on complete data and showed that over 1,500 sailors had applied for release from wrongful impressment. This came as something of a shock. one Congressman commented:

The list...exceeded in number anything he had expected. He thought... that the subject demanded investigation...Will the United states tamely submit to see some of its best citizens torn from their families and friends... Shall we see another country pursuing measures hostile to our 
commercial rights and make no effort to correct the mischief? ${ }^{32}$

The answer was a resounding 'no'. Talks were resumed with Merry. ${ }^{33}$

Also, an Act for the more effectual preservation of peace in the ports and harbors of the United States and the waters under their jurisdiction, passed on March 3, 1850. This contained a clause much like the act that Jefferson's friend, Senator Nicholas, had struck down:

Whenever any officer of an armed vessel commissioned by any foreign power, shall on the high seas, commit any trespass... on board any vessel of the United States... it shall be lawful... to interdict the entrance of the said officer... within the limits of the United States. ${ }^{34}$

This was the first real retaliation from America and could have been quite a problem as British war ships were stationed in the Indies and Canada and often travelled through United States waters. In response, British officials again charged America with giving deserters false American citizenship papers. Madison replied that they were making "a very... unwarranted assertion." This did not stop Merry from attempting to get Madison to admit that illegal certificates were often issued. ${ }^{35}$ Madison would, of course, admit nothing. After these exchanges, in April, 1805, Merry was never to receive another complaint about a specific instance of impressment. One reason for the United states government to keep the lid on was economic. If America went to war she would lose her neutral nation 
freight carrying status and thus lose her merchant marine. The merchant fleet and the money it brought in had been one of the carrots angled before the American public during the revolution. Because of the importance attached to commercial well-being there was little desire to rock the boat where it was concerned. Then, in June, Pitt decided to obstruct American neutral trade. ${ }^{36}$

On June 25, the Duke of Montrose spoke in the House of Lords :

According to the navigation act there could be no communication between the United states and the British West India islands except in British bottoms. But a power was given to the governor of every island to allow the importation of provisions... in case of necessity. It having appeared, however, that some irregularities had arisen in the exercise of this power and that a too general importation had been permitted, directions were sent out to the governors not to make too frequent use of the discretion. ${ }^{37}$

Now Britain was hitting America where it lived, in the purse strings. Negative response was only a matter of time.

At around the same time James Monroe returned to London and called on the new Foreign Secretary, the Earl of Mulgrave, to talk once more about impressment. ${ }^{38}$ But things had changed. The government and the navy now belonged to Pitt. Addington men were firmly on the outside. Complaints had even been heard in Parliament:

Earl Darnley rose and expressed his regret... [that] the persons who had the superintendence of the naval department... seemed to have come 
into office upon the specific pledge of wholly reversing the system of their predecessors. ${ }^{39}$

certainly this was a bit of party rhetoric, but it aptly described Pitt's new view towards the carrying trade in the West Indies.

Monroe waited for three weeks after his meeting with Mulgrave with no response. At last he decided to pressure the secretary by announcing his imminent return to America. ${ }^{40}$ This got Mulgrave's attention. He wrote Prime Minister Pitt on October 12 :

Mr. Monroe's notice of his leave... is sudden and unexpected, some answer good or bad... must be given to Him... it would have an awkward appearance... if he were suffered to depart Home without any answer from this Government. ${ }^{41}$

Mulgrave sent Monroe a note in late November which, according to Monroe, "revived the expectation" that he might see some action. Unfortunately, Mulgrave was only concerned with the Pitt ministry's image. As soon as Monroe told Mulgrave that he'd decided to stay, the cabinet immediately put off any decision on the subject. ${ }^{42}$

For four years Jefferson and Madison had consistently pursued a course of peaceful diplomacy. They had worked to keep the responses of their country and its government both calm and rational. Now, whether they liked it or not, that was all to change. With no talks in sight and the West Indies profit gone Americans began to call for serious action, even war. 


\section{CHAPTER V}

\section{THE TREATY OF 1806}

Soon after Congress opened in December of 1805, British chargé Anthony Merry wrote of a tendency they had to "combine the recent Detentions of American Ships with the Impressment of American seamen." In this way, he concluded, Congress hoped "to excite universal Resentment against us."1 He was absolutely correct. The Ninth Congress marked the end of a moderate American attitude towards impressment. The issue had been allowed to drag on for too long and was now beginning to demand resolution. Secretary of state Madison saw the solution in new negotiation and the administration formulated a strategy of economic coercion to push through its diplomatic agenda. Madison advised Jefferson,

If a commercial weapon can be properly shaped for the Executive hand, it is more and more apparent to me that it can force all the nations having colonies in this quarter of the globe to respect our rights. ${ }^{2}$

Madison's thoughts seemed aimed at an export embargo for the West Indies designed to coerce England into relaxing her regulations. ${ }^{3}$ Within two months Monroe advised the same course of action. 
We shall get nothing from any but by force, but... with a subtle pressure, which however must be unequivocal and decisive... we may succeed in what is right with any of them." 4

This was an even stronger sentiment than Madison's and it came from the man who was in almost all respects America's ambassador to England.

Jefferson took the advice to heart. In his message at the opening of congress he stated that:

the authority of reason... imposes on us the obligation of providing an effectual and determined opposition to a doctrine so injurious to the rights of peaceable nations." 5

The American government, even at the highest level, felt a need, almost a compulsion, for action in the face of the long standing difficulties with impressment. These were stronger words than had ever before been put to the subject. After the message had been read, Senator William Plumer commented, "The message is more energetic and warlike than any he [Jefferson] ever sent to congress."6 So it was readily apparent that the usually pacifist Jefferson administration was rapidly reaching the end of its rope.

The Jefferson administration was taking a tougher approach. Their plan called for sending congress a special anti-British message. To be included was an October 15 1805 despatch from Monroe which contained a strong call for coercive measures. He warned that Britain intended "to push their fortune in every practicable line at our 
expense." Recent seizures of men and ships were simply experiments to see how far Britain could push America without retaliation.

If it succeeds, they will...pursue the advantage gained to the greatest extent in all the relations susisting between the two countries, more especially in the empressment of our seamen.

Monroe recommended immediate pressure be placed on Britain as her "colonies are dependent on us." only in this manner, it was felt, could Britain's depredations be stopped.

The message was planned for the second week of January, 1806 but was delayed for several days. ${ }^{8}$ The reason appears to have been cold feet since Jefferson's portion of the communiqué was considerably toned down by the time of its release on the 17th. Now, on impressment, Jefferson would only say that U.S. "remonstrances had never been intermitted."9 This amounted to a statement that though nothing had ever been done about impressment at least America had never stopped complaining about it.

This was not a very strong message to send, particularly considering the administration wanted to persuade congress to take decisive action. It seems probable that Jefferson felt Monroe's dispatch was bad enough, and that congress didn't need him to breathe fire and brimstone as well. Senator James Logan described the dispatch as containing "a spirit of war and blood."10 and 
John Quincy Adams felt it was "full of bitterness against England, and urging strong and decisive measures." "Which indeed it was. Adams later stated that, "Mr. Monroe was known not to be friendly to England."12 Which would seem to qualify as a vast understatement. It would appear then, that Jefferson was right to tone down his portion of the missive lest congress come up with more serious action than he had planned for. If this was the case then Jefferson needed to tone his message down even more.

Representative Andrew Gregg of Pennsylvania surprised the House with a resolution calling for total non-importation of "goods, wares or merchandise, or the growth, product or manufacture"13 of Great Britain or her colonies. The next day, samuel smith submitted a resolution proposing selective non-importation. ${ }^{14}$ These two sides quickly became the focus of intense discussion in the Senate. Uriah Tracy of Connecticut was "decidedly" against non-importation as were George Logan and Abraham Baldwin of Georgia. These representatives of the eastern states feared non-importation would hurt America as much as Britain. John Quincy Adams, generally on the side of the administration, agreed. Joseph Anderson of Tennessee finally proposed to modify the resolution. Adams drafted a plan which now called for the President to send an envoy extraordinary to London. ${ }^{15}$ 
The senate called on the President "to demand and insist upon" compensation for seizures "particularly respecting the impressment of American seamen." This course of action was approved by the senate February 5 , $1806 .^{16}$

Meanwhile, several more plans were brought up in the House. Joseph Clay of Pennsylvania proposed a "mild but firm" ban "likely to induce Great Britain, in particular, to recede from the unjust pretension she has set up."17 Any country who refused to allow United States vessels into its colonial ports would likewise be stopped from entering American ports. Jacob Crowninshield added a plan calling or an embargo on all trade with Britain. He explained:

We are merely about to prohibit the importation of British goods in consequence of her having seized our vessels... and in consequence of her seizure of American citizens protected by the American flag. ${ }^{18}$

He was not alone in calling for strong measures. James Sloan of New Jersey also called for an embargo until Britain agreed to "equitable arrangement"19 on impressment and seizures.

None of these plans received serious consideration. Instead, attention went to Joseph Nicholson's diplomatic proposal of partial non-importation:

By laying a prohibition on the importation of all articles received from Great Britain... We shall be laughed at...for adopting a system altogether impractical because we cannot adhere to it. 20 
Instead, his plan called for continuing the import of cheap woolens, rum, salt and hardwares in an effort to cushion the economic blow to American merchants. The debate on commercial restrictions quickly became one between Gregg's total non-importation and Nicholson's partial plan.

Madison and Jefferson were both in favor of limited non-importation though they only spoke their views in private. John Quincy Adams reported on February 13, 1806:

[Madison's] system of proceeding towards Great Britain is...a retaliating navigation act; and aggravated duties on articles imported from her. This is doubtless the President's favorite policy.21

Two weeks later he confirmed his assumption, writing, "I dined at the President's...His own preference is manifestly for Nicholson's resolution."22 Jefferson and Madison were unwilling to interfere directly in the day to day workings of Congress, believing as strongly as they did in the separation of the executive branch from the judicial and the legislative. Their usual method was to work through favorably disposed allies in both houses.

Now, hoping to calm Congress, Jefferson sent a note from Lord Mulgrave promising that the "American question" would soon be settled. ${ }^{23}$ It turned out to be an empty promise. After a month went by with no further word from Mulgrave, the administration finally sent a report on imports and exports demanded by Congressman Randolph before the House would consider Gregg's proposal. This was 
typical of the Jefferson-Madison approach. Neither man had any real desire for war, or even to be much of a hard-liner. When they saw that a direct approach had worked, as in securing the statement from Mulgrave, they were often too quick to take the pressure off. Then, when the lessening in pressure caused results to drop off, they would turn the heat up again.

On March 8, Madison sent the House a report on impressments requested over two months before. Three days later he wrote Monroe that he and the President were still "waiting with solicitude" 24 for the British cabinet's promised reply. Their patience was wearing thin. Jefferson clearly felt it was time for some action.

The love of peace which we sincerely feel and profess," he wrote on March 18, "has begun to produce an opinion in Europe that our government is entirely in Quaker principles... This opinion must be corrected when just occasion arises, or we shall become the plunder of all nations. ${ }^{25}$

It must be stressed that Jefferson said this in private, apparently trusting that he had already goaded Congress enough, if not too much.

Debate on Gregg's resolution ran from March 5 to March 13. It soon became apparent only a minority supported full nonimportation. Gregg's proposal was defeated 70 to 47.26 The House then spent four days debating Nicholson's plan which passed on March 18 with a resounding 87 to 35 vote. ${ }^{27}$ 
This bill then passed the Senate on April 15 and Jefferson signed it into law three days later. ${ }^{28}$

Congressional debate confirmed Phineas Bond's observation of the tendency to merge the anti-British complaints of seizures of American ships and impressment. Gregg had placed impressment first among a long list of grievances in his resolution. Barnabas Bidwell noted in a discussion on seizures that impressments were occurring at a far greater rate than ever before. ${ }^{29}$ some extreme Republicans even said they now accepted the possibility of war with Great Britain as the only means of solving America's problem, though they generally denied it would have to go that far. Instead, the resolve for war on America's part would be sufficient to deter Great Britain. ${ }^{30}$ Critics thought the uproar over impressments was excessive and somewhat hollow. Joseph Nicholson felt it was "the carrying trade alone" that was responsible for national outrage.

It was a matter of little surprise, that gentlemen had so long slept upon a subject [impressment], on which they now appeared to manifest so much zeal...strong measures were not then the order of the day, nor would they be now, if the impressment of American seamen was the only ground of complaint. ${ }^{31}$

The crusade against impressment was, to him, a hoax. Rufus King was also against the extreme measures being taken against impressment. He felt the non-importation act was designed to batter Britain into concessions. King wrote 
Sir Francis Baring, a London banker, that the act "must not...occasion temper on the side of England. The two countries should be friends, and a captious temper should not...prevent them being so."32 His use of the word 'captious' indicates that he too felt American anger to be something of a sham.

Perhaps it is true that some men used the populist issue of impressment to further their desires for unrestricted trade with the British West Indies. However, the argument could also be made that men used the hard economic issue of the carrying trade to force the government to pay attention to their concerns about impressment. I believe Nicholson and King were wrong. At this point many Americans seemed to feel affairs were at a critical state. Like Jefferson they believed acquiescence was out of the question. This is not to suggest that Americans hungered for war. At this point the course most favored was negotiation backed with commercial sanctions. ${ }^{33}$ To start the negotiations, Jefferson decided to send an envoy extraordinary to London. William Pinckney agreed to take the job on March $13 .{ }^{34}$ The decision to send the envoy was probably due to the arrival of some promising news. The Jefferson administration had learned of Prime Minister Pitt's death and the new Grenville-Fox administration in early February. Monroe wrote Madison that "the arrangement of the new Ministry was 
completed... in the course of the last week. It makes... a thorough change of character... at least in respect to us." 35 This news, coupled with the action in congress could hardly have helped but spark excitement. Indeed, Jefferson wrote in June:

Every communication from Mr. Monroe strengthens our expectation that the new pretence of the British to control our commerce with belligerents' colonies will be properly restricted, and the outrages on our seamen brought to an end. ${ }^{36}$

However, neither Jefferson, Madison or Monroe ever thought all obstacles to a settlement had been removed. This change in ministry was simply a favorable component. By mid-1806 the re-export trade and impressment were of paramount importance. Madison wrote to Monroe and Pinckney:

The importance of an effectual remedy for [the impressment of American sailors], derives urgency from the licentiousness with which it is still pursued, and from the growing impatience of this country under it.

This plainly illustrates why the Jefferson administration was hedging their bets, even though the Grenville-Fox ministry was friendly to the United states. Impressment was still occurring, and often. Madison continued:

So indispensable is some adequate provision for [impressment], that the President makes it a necessary preliminary to any stipulation requiring a repeal of the Act shutting the market of the $U$. States against certain British manufactures. ${ }^{37}$ 
This was not political opportunism, but a genuine reflection of the strength of feeling excited by impressment in this country. Judge John Tyler wrote to Jefferson, "I would rather not exist as a man or nation than to suffer such violations of the rights and liberty of our fellow citizens." ${ }^{38}$ A week later Wilson Cary Nicholas advised that, "the impressment of our seamen is a thing that the honor, the feelings and the interest of the United States calls aloud upon the government to put an end to." 39 clearly there was a great deal of anger on the subject which Jefferson would have been ill-advised to ignore.

Britain's new government did want good relations with America, but not at the expense of vital British interests. After Monroe re-opened discussions on impressment on February 25, the new Admiralty board responded with a very old argument. The American proposal "would, if adopted, be attended with the most pernicious, if not fatal consequences to His Majesty's naval Service." 40 This had been the Royal Navy's response for years. As always, the need for impressment reflected a shortage of sailors. The navy had continued to expand throughout 1806. In January of 1806 Britain possessed 590 ships and 111,237 sailors. By January of 1807 the navy consisted of 650 ships and 119,855 sailors. ${ }^{41}$ Thus, though the number of sailors had risen, the per capita number of sailors per ship had 
dropped. With France attempting to take over all of Europe, Britain needed every sailor she could grab. To compound problems, Fox fell fatally ill three days after Pinckney arrived in London. Lord Auckland, an ally of Lord Grenville's with long diplomatic experience, was chosen to take Fox's place in negotiation with the Americans. ${ }^{42}$ This was not necessarily good news. Jefferson was afraid Auckland was "too much wedded to the antient maritime code and principles of England."43 This because of the Lord's long-time service in the diplomatic arena. Auckland seemed to bear this opinion out, when, at his introductory dinner, he declared, "I trust we shall be able to do some good to mankind, if your powers are sufficiently extensive."44 Which was not exactly extending the olive branch.

However, to the Americans there still remained a ray of hope. Also assigned was Henry Vassal Holland, Fox's nephew. Early in 1806, Monroe had reported that Holland had written a pamphlet expressing "very liberal sentiments toward the United States." 45 The Jefferson administration hoped that Holland would extend a mitigating influence on Auckland whom they expected to be intractable.

With the new British team settled negotiation began again on september first. As talks commenced it became clear that the British would be hewing closer to Auckland's point of view than Holland's. Still, there was a sign of 
compromise. The British negotiators referred to impressment as "extremely delicate and embarrassing." They requested to know "precisely" what the United States would put in a treaty to guarantee the restoration of British sailors. It was their fear that the American plan would turn United States merchant ships into "receptacles for deserters." They themselves "felt the strongest repugnance" to a renunciation of the right to impress "such seamen as should appear to be their own subjects." They suggested instead that America issue "authentic documents of citizenship" whose form would be settled by treaty" and would "completely protect those to whom they related." 46 Though this was a significant concession the talks soon stalled. The Americans, always leery of this sort of paperwork, found "that it was besides impossible that we should acknowledge in favor of any foreign power...such jurisdiction on board our vessels... as this sort of impressment implied."47 Monroe and Pinckney seemed to fear that the British negotiators were trying to catch them in a game of 'slip-up'. A mistaken word could then lead to Britain claiming that America had acknowledged Britain's basic right to impress sailors.

Meanwhile, Auckland had received alleged examples of fraudulent American protections from the Admiralty. He showed these documents to the Americans and "insisted much on the difficulty which this notorious practice would raise 
in framing any Article for the due security... of the British Navy." It was a legitimate concern, yet, despite their apparent reservations, Auckland and Holland set out the American plan for the cabinet's consideration. They did, however, recommend that "whatever arrangements may be thought advisable or expedient on this subject" be temporary "so that its defects may eventually be reconsidered and rectified." 48 After this advice, a sort of diplomatic buckling of safety belts, the British negotiators told Monroe and Pinckney "that the several considerations had been sufficiently discussed, to be laid immediately before the King's Ministers for further instructions."49 The four men agreed to adjourn until November fifth.

When the cabinet finally sat to discuss the proposal it was November fourth. They agreed only that if any article was to be adopted the right to impressment itself had to be preserved "in Status Quo by express Saving Provisos." 50 In other words, no deal.

Though initially rejecting Britain's 'counter proposal', Monroe and Pinckney gave in to British requests to continue negotiations. Auckland drafted a note to the Americans immediately, promising:

that instructions have been given and shall be repeated and enforced; for the observance of the greatest caution in the impressing of British seamen; and that the strictest care shall be taken to preserve the citizens of the 
United states from any molestation or injury; and that immediate and prompt redress shall be afforded upon any representation of injury sustained by them. ${ }^{51}$

Which did nothing to solve the problem but was certainly very polite. In fact, the British had been being polite in this manner for some years already, so this assurance really meant nothing.

A full treaty was finally signed by the American team on New Year's Eve, however, there was a formal silence on impressment. ${ }^{52}$ on February 3, Madison wrote the negotiators:

If no satisfactory or formal stipulation on the subject of impressment be obtainable the negotiation should be made to terminate without any formal compact whatever, but with mutual understanding, founded on friendly and liberal discussions and explanations, that in practice each party will entirely conform to what may be thus informally settled. ${ }^{53}$

At this time, of course, he had no knowledge of the already signed treaty. Still, from his words we find his reaction on March 3, when the treaty did arrive, unsurprising. When Madison saw it contained nothing on impressment he said that "he did not think it would be possible to ratify the Treaty, without an Article that should satisfactorily provide for the object."54 That 'object' was, naturally, the end of impressment.

Jefferson rejected the treaty as well. ${ }^{55}$ This rejection marked the end of friendly Anglo-American 
relations for years to come. The next phase began a slow downward spiral that led finally to war. 
CHAPTER VI

\section{THE CHESAPEAKE-LEOPARD ENCOUNTER}

Administration leaders spent the Spring of 1807 trying to think of a way to get Britain to make concessions on impressment. On March 17, Madison urged a plan to renounce the use of British sailors in the American carrying trade. ${ }^{1}$ Albert Gallatin, the Secretary of the Treasury, began to examine the possible impact of this renunciation. He found that at least 9,000 of the 69,000 sailors in the United States navy and merchant marine were British. Gallatin warned that Madison's proposal could "materially injure" American commerce and navigation "much more" than "any restrictions" the British government could lay "supposing no treaty to take place." The sacrifice would be "too great for the object." He would only recommend Madison's plan if a failure to procure a treaty would "lead to hostilities, or to a state of things equivalent thereto." Again, the primary consideration was commerce. The only thing that could hurt trade more than impressment was the loss of 9,000 British sailors and the only thing worse than that was out and out war.

Madison was forced to agree that Gallatin's numbers had to "command just attention." He proposed instead to 
renounce the services of all British sailors except those with more than two years outside their own country's services. He wrote to Jefferson that General Henry Dearborn, the Secretary of War, and Robert Smith, the Secretary of the Navy, were, "willing to go to great lengths on this subject. The case of impressment is...urgent. Something seems essential to be done, nor is anything likely to be done without carrying fresh matter into the negotiation." ${ }^{3}$ Unfortunately this came on the heels of Gallatin's statement. The Jefferson administration was no longer ready to take what seemed drastic action. Jefferson replied, "On the subject of the British treaty...the more it is developed the worse it appears." ${ }^{4}$ The President felt the number of British sailors in American employ made it:

prudent...to drop the idea of any proposition not to employ them. The best course is to let the negotiation take a friendly nap and endeavor in the meantime to practice on such of its principles as are mutually acceptable. ${ }^{5}$

America, it seemed, could not afford to renounce British sailors any more than Britain could renounce impressment. Madison, at this point, began to "suspect" that the treaty would have to be limited to the "subject of Impressments, leaving the Colonial Trade with other objects to their own course." He continued to push his views, however, recommending "fresh concessions" be made. ${ }^{6}$ 
The advice was not followed. The administration as angered by the human tragedy of impressment but they were not ready to destroy American commerce over it. In the instructions to Monroe and Pinckney finished on May 20 , only the proposal to prohibit employment of those with less than two years service survived. This was now to be offered only "in the event of a rejection of every arrangement already authorized." If Britain rejected this final offer, Monroe and Pinckney were to refer the problem back to Washington. However, it was hoped that talks could be made as long as possible. As Madison said,

$$
\begin{aligned}
& \text { As long as negotiation can be honorably } \\
& \text { protracted, it is a resource to be preferred, } \\
& \text { under existing circumstances, to the preemptory } \\
& \text { alternative of improper concessions or inevitable } \\
& \text { collisions. }
\end{aligned}
$$

The feeling seemed to be that as long as the two countries were talking they at least weren't at war. At the same time, Madison refused to aid the British in recovering their deserters from American ships. He claimed America and Britain had no treaty requiring restitution of deserters. ${ }^{7}$ This stance was used as a carrot on a stick to help Madison reach his goal of a combined treaty to end impressment at sea and recover British deserters.

Britain, of course, was not disposed to drop impressment, and Madison's proposals fell, not surprisingly, on deaf ears. All this work with so little 
progress helped to create a tense atmosphere and eventually led to the attack on the chesapeake.

In December, 1806, British minister David Erskine went to Madison about the case of several deserters from a British ship who were being sheltered in Boston. Madison refused to help, saying again that:

as no existing article of the Treaty between Great Britain and the United States [Jay's Treaty] gave any authority to the Government of the United States to exercise such a power, they did not dare interfere. ${ }^{8}$

clearly, he was still hoping to attach this issue to that of impressment. On February 1, 1807, Madison tried again to tempt Erskine, telling him that a formal treaty would produce a situation where "every Facility would be afforded by the Government and the People" for the recovery of British deserters. He claimed "a great many would be restored." Of course nothing was done and the whole situation sat on pins and needles, an accident waiting to happen.

In early January five sailors had fled from the H.M.S. Melampus, anchored near Hampton, Virginia. ${ }^{10}$ Thomas Hall Parker, Mayor of Norfolk, refused to deliver the men since neither federal nor state law had provisions for such cases." Secretary of the Navy, Robert Smith, listed the deserters who were now alleged to be on $t$ he chesapeake and ordered recruiting officers "in no case to enter deserters from British ships of war." Commodore James Barron, 
captain of the Chesapeake, replied that three of the deserters were on his ship but were undoubtedly Americans pressed into the Royal Navy. ${ }^{12}$ British naval officers soon put together their own theory of American behavior.

Captain J.E. Douglas wrote on April 15 saying refusal to ratify the Treaty of 1806 was

only a Finesse on their part, to prevent His Majesty's Ministers applying for the many Thousand British Subjects employed in the Navigation of the Vessels of the United states."13

That this was untrue is obvious but it is an illustration of the anger and frustration felt within the British navy over American conduct.

Admiral George Berkeley, in command of the British ships on the North American station, reported to the Admiralty that "the open and avowed protection" given to British deserters necessitated "some explanation from the American government." British officers who tried to get their men back were often subject to "the most glaring insults" from the local populace. ${ }^{14}$ Clearly, Admiral Berkeley was reaching his limit. On May 31, he discovered that one of his ships, the Driver, had been expelled from Charlestown under threat of attack. It was the last straw. The next day Berkeley ordered his commanders to search for the British deserters known to be on the Chesapeake. ${ }^{15}$ Captain Douglas, anchored within sight of the Chesapeake assigned the search to the Leopard, a ship 
nearly equal to the chesapeake. He had a much larger ship at his call, the Bellona, and had it searched the Chesapeake an honor-bound American resistance might have been averted. Such was not to be the case.

Late in the afternoon of June 22, the Leopard intercepted the Chesapeake and asked permission to send over a boat carrying dispatches. This was not unusual and the request was granted. When the boat arrived, however, the British lieutenant in charge gave Commodore Barron a note from the captain of the Leopard along with a copy of Berkeley's orders and then demanded the British deserters. Barron refused and before the chesapeake's decks could be cleared for action the Leopard had fired a warning shot and then a broadside into the frigate. After fifteen minutes of fire from the Leopard, the Chesapeake surrendered and the British boarding party returned and took four suspected deserters. ${ }^{16}$

The sight of the damaged frigate and news of three dead and eighteen wounded among her crew set off a violent chain reaction along the East coast. In Norfolk a crowd rioted and destroyed water casks from two of the British ships in Chesapeake Bay. ${ }^{17}$ New Yorkers attackers and heavily damaged a British ship. Editor Thomas Ritchie of the Richmond Enquirer called upon the President to convene Congress to decide on the issue of war. $^{18}$ War was definitely an option and the fear was that the American 
public rather than the America government would make the decision. Jefferson advised restraint in the vicinity of Norfolk so that any decision could be left to Congress. ${ }^{19}$ Three days later the cabinet banned all British warships from American waters and sent the aptly named Revenge to England to demand a disavowal of the attack, restoration of the men and the recall of Admiral Berkeley ${ }^{20}$

Public response in America was mostly anger. At a public meeting in Baltimore, senator samuel smith called for "War-in case...satisfaction is not given." 21 though this sounded as if the senator was standing tall, the reality was that satisfaction was almost certainly forthcoming. still, from the reactions of many Americans, this seems to be a fact many people were not sure of. Jefferson's friend, wilson Cary Nicholas said he was ready to "encounter war" since there was "no spirit which ought to be cherished with so much care by those who govern a young country as national pride and a regard to national honor."22 And Congressman James G. Jackson of West Virginia feared that "tame submission to such outrages" would "disgrace the Government and its Friends" paving the way for despotism. It began to look as if Jefferson were suffering a crisis of decision, or even worse, was afraid to take action. This was not the case. Throughout July the president reminded his correspondents that the common usage of nations required America to give Britain a chance to make 
reparations. Besides, American merchant and war ships would be left vulnerable if war were so suddenly declared. ${ }^{24}$ For all Jefferson's words the tension continued. After the destruction of the water casks, on July 8 , British Captain Douglas blockaded Chesapeake Bay. ${ }^{25}$ It was a dangerous move. Jefferson advised the Secretary of War that "the British commanders have their foot on the threshold of war."26 It seemed that there might indeed be a conflict. The crisis only began to abate on July 11 when Jefferson learned that the attack on the chesapeake was not the result of prior orders from London. still, it was not until the fifteenth, when Douglas calmed down and dropped the blockade, that the danger of war passed. ${ }^{27}$

At this point American demands for redress for the attack on the chesapeake changed. The recall of Admiral Berkeley was dropped. Now the administration demanded "security for the future" to be achieved through "an entire abolition of impressments from vessels under the flag of the United States." This was hoped to be made possible "without the authorized rejection from the service of the United states of British seamen who have not been two years in it." 28 This would appear to be a case of America feeling they were one-up on England and now in a position to press their demands while making no corresponding concessions of their own. 
Meanwhile, public sentiment began to drift away from war. Albert Gallatin wrote Madison that New Yorkers "do not appear to me to be in favor of war." By this time, though, the immediate danger of war had passed. Canning wrote Monroe on July 25, assuring him that the British Government would give "the most prompt and effectual Reparation" if the British government was found to be the aggressor. The Foreign Secretary also said, however, that he was "not at present enabled to communicate" any particulars. ${ }^{30}$ Monroe, at this point, knew absolutely nothing of the chesapeake incident and wouldn't hear from the United States government for over a month. Though he had to be somewhat mystified he thanked Canning for the assurance that "this unfortunate occurrence was not authorized by his majesty's government." "31

Two days later, Monroe learned of the attack from news accounts. On July 29 he met with Canning and brought up the attack on the chesapeake. He asked the cabinet to admit the incident was "a flagrant abuse" of authority and to give Washington "a frank disavowal of the principle on which it was made."32 Which meant give up impressment. Unfortunately for Monroe the cabinet wasn't as sure about the incident as he was. After all, America had twice refused to return identified deserters. It hardly seemed the sort of mishap designed to get Britain to renounce a practice they had been doggedly hanging on to for 
centuries. Canning replied to Monroe on August 3, assuring him "that His Majesty neither does or has maintained...a right to search ships of war...for deserters... If it shall appear that the [attack] rested on no other grounds" than a right to search foreign warships, the British government would have "no difficulty is disavowing that act."33 The wording here indicates the British government felt reasonably sure that there would be some sort of extenuating circumstances.

The next month Canning decided to announce a Royal Proclamation which would repeat the renunciation of a right to search foreign warships, while announcing Britain's intention to continue impressment from merchant ships on the high seas. ${ }^{34}$ Canning had already spoken of the idea with Monroe in early September and had been told that the American envoy was forbidden to separate reparations for the Chesapeake from the demand to end high seas impressment. ${ }^{35}$ Monroe followed this refusal by submitting a formal demand for reparations and for the end of impressment. Canning's proclamation had to be put on hold. ${ }^{36}$ The British cabinet instead announced an intention to send a special minister to America to settle reparations on $t$ he Chesapeake. This note was delivered to Monroe on September 23, in it Canning refused to handle the Chesapeake and impressment issues together. ${ }^{37}$ This seemed very high-handed to the Americans. On October 19, Monroe 
and Pinckney asked Canning if the proclamation with its insistence on separation of the chesapeake from impressment was designed to "shut the door against negotiation and concession." Canning replied that it was merely intended to state the British position. At the same time he also made it clear that Britain would not retreat from the practice of impressment:

He said...that he ought not to leave us under the impression that there was any prospect that the Government of Great Britain could recede from its declared pretensions relative to searching on the high seas the merchant ships of neutral nations for British seamen. ${ }^{38}$

This left the Americans very little room to maneuver and when Canning formally terminated negotiations on october 22 it came as little surprise.

Jefferson now began to prepare for the possibility of war. He first ordered a line beyond which British ships would not be allowed to pass. He then used his annual message to Congress for a powerful attack on England. "With the other nations of Europe our harmony has been uninterrupted, and commerce and friendly intercourse have been maintained on their usual footing." Great Britain, however, threatened the "peace and prosperity" of the nation. Now America would have to "restrain wrong by resistance." 40 These were by far the harshest words Jefferson had yet used, a virtual call for war. Yet on October 26, the National Intelligencer, a government 
mouthpiece, offered a choice between war or "surer

reparation through the medium of commercial regulation."41

Clearly, if Jefferson had been contemplating war he had

changed his mind. It is even possible that he never

planned for war and was only trying to gain leverage at the bargaining table.

On December 14, His Majesty's Royal Proclamation of

October 17 reached America. It was not received favorably. On December 17, Jefferson drafted a recommendation that Congress put an embargo on all American shipping. ${ }^{42}$ This recommendation was sent to the senate the same night.

The communications now made, showing the great and increasing dangers with which our vessels, our seamen and merchandise, are threatened on the high seas and elsewhere from the belligerent powers of Europe, and it being of the greatest importance to keep in safety these essential resources, I deem it my duty to recommend the subject to the consideration of Congress, who will doubtless preceive all the advantages which may be expected from an inhibition of the departure of our vessels from the ports of the United States. ${ }^{43}$

This was probably the strongest measure Jefferson could have taken without actually pushing for a declaration of war. Congress was in apparent agreement as they passed the Embargo Act in just four days. When Jefferson signed it into law he was admitting his policy of negotiation had failed. He had fallen back as his last resort on non-importation and embargo as the last peaceful means of supporting America's ongoing quest for concessions. 
IMPRESSMENT TAKES A BACK SEAT, 1807-1812

Late in 1807 attention began to turn away from impressment towards British and French attacks on neutral commerce. President Jefferson noted, "The decrees and orders of the belligerent nations... amounted nearly to a declaration that they would take our vessels wherever found." 1 Jefferson was referring to Britain's problematic orders in Council, passed November 11, 1807. This order prohibited under pain of capture, trade with any part of the European continent under French control, which was most everything. Britain had passed the decree in response to similar measures, the Berlin and Milan Decrees, passed by Napoleon. It is easy to see that having entire ships seized was a problem that outweighed having a few members of the crew taken away. For the next three years impressment lacked major importance as a political issue, but the practice continued unabated. Requests for the release of sailors are the only guide to the number of men taken. Four hundred and ninety-eight men were impressed in 1807 while 514 were impressed in 1808. By 1810 the number had jumped to 1,047 and in the first nine months of 1812 another 830 releases were requested. ${ }^{2}$ 
Though United States diplomats sometimes broached the subject, their attitudes were changeable. Albert Gallatin told British special envoy George Henry Rose in March, 1808, that "nothing of a real difficulty remained between the Two Countries but His Majesty's orders in Council." Rose noted that Gallatin repeated this statement "dwelling upon the word 'nothing' with particular emphasis."' But in August, 1809, Gallatin wrote David Erskine that there was little chance of an Anglo-American treaty without an agreement on impressment. ${ }^{4}$ This change in attitude may have been caused by the failure of British-American negotiations. Only days after the United states embargo had been passed, George Rose arrived to discuss reparations for the Chesapeake. The Jefferson administration immediately agreed to separate this issue from impressment. 5

Though Rose's mission was in the end a failure it did cause this change in American policy. Madison's new instructions to William Pinckney told him,

You are authorized... in the event of a repeal of the British orders, and of satisfactory pledges for repairing the aggression on the Chesapeake, to enter into informal arrangements for abolishing impressments. 6

This indicates a new order of priority, with impressment clearly taking the back seat to the orders.

The temptation is to blame collapse of negotiations on American intransigence, the stubborn insistence on linking 
impressment to other diplomatic issues. In this case, however, the Royal Proclamation of October 17, 1807, seemed to bar further negotiation. Jefferson admitted, "A proclamation of that Government [Britain]...seems to have shut the door on all negotiation with us."7 David Erskine wrote to London the day after Jefferson signed the embargo act warning that the Proclamation had convinced the Jefferson administration that Britain was unwilling to make major concessions. ${ }^{8}$ Not for the first time, the news fell on deaf ears.

One reason for the administration's lessening of impressment's importance could have been the waning of public interest. Only occasionally after 1807 did outrage at impressments hit the papers. 9 Congress was like-minded, rarely discussing the issue, and generally favoring commercial sanctions as retaliation for the more important Orders in Council through November, 1811.

Dislike had grown toward the embargo, however, and Congress turned to a less severe measure. Macon's Bill \#2 became law in May, 1810. Repeal by one of the belligerents of its commercial restrictions had to be followed in ninety days by repeal of its enemies' decrees or non-intercourse would be sustained against the continuing offender. Napoleon repealed the Berlin and Milan Decrees towards America on November 2, 1810. On that day the United States government told Pinckney to notify Britain that they had 
ninety days to revoke the orders in Council. Britain refused, denying the French Decrees had been truly repealed since they had only been relaxed towards America. Congress then legislated a new non-intercourse act with Great Britain to begin March $1,1811 .{ }^{10}$

Even after this set back, President Madison still thought there was a good possibility of settling the issue.

Lord Holland [is] Prime Minister....a new parliament [is] to be called... It is highly probable that some natural change in the general policy of the [British] Government in relation to this country... will result."

His Secretary of State, James Monroe, was also hopeful for peace claiming he would be "most happy indeed" if the divisive issues could be settled on "reasonable and satisfactory grounds."12 This new administration was still operating within the framework of Jefferson's previous policy. War was damaging to commerce and something to be avoided if at all possible. Congress, for the moment, agreed. In February, 1811, a vote on a resolution demanding an end to impressment and the revoking of the orders in council failed, gathering only 21 votes out of $104 .{ }^{13}$ Yet despite this apparent goodwill, the British were taking no chances. John P. Morier, the British chargé d'affairs, wrote to sir Herbert Sawyer, the new Commander of the North American Station in May, 1811:

The subject of impressment has always been one by which the feeling of this nation has 
been kept alive in its animosity against Great Britain... Were I to venture to give an opinion on the subject of impressment in general, it would be for...its abandonment in practice... because I am confident that no possible advantage which can accrue to the service...can compensate for the evil which a constant state of irritation between the two nations must create. ${ }^{14}$

Hoping that an Admiral would agree with his opinion was wishful thinking on Mr. Morier's part, however, in a short time his assessment was to prove correct.

The new British minister to America, Augustus John Foster, arrived in Washington on June 30,1811 . From President Madison's earlier remarks on the new British cabinet it would seem hopes were riding high that new negotiations would prove fruitful. Indeed, Monroe began talks three days after Foster's arrival, but impressment was ignored in favor of the French Decrees and the orders in Council. ${ }^{15}$ Unfortunately, Foster had been instructed to give very little in the upcoming talks.

Altho' it is the anxious desire of His Royal Highness...to avoid a rupture with the United States of America... It is also expedient that the American Govt. should be made sensible, of the great extent of the means, which this country possess, of affecting the commerce and industry of the United States... Without resorting to the extremity of war...you will use your discretion in suggesting these considerations... at the time... Which may appear most convenient and useful. 16

Though he did not use these suggested threats, Foster did, on his own initiative, attempt to explain how the U.S. government had been duped by the French. He hoped that 
through his efforts "the delusions attempted by the Government of France have now been made manifest and the perfidious plans of its ruler exposed."17 These hopes were in vain. Monroe, unwilling to give an inch on the subject, attacked the British position point by point. Foster's only reply to this long and detailed rebuttal was to ask if the President would now "rest satisfied with the partial repeal of the Berlin and Milan Decrees?"18 The flippant reply surely angered Monroe and Madison who were obviously quite satisfied with partial repeal as long as it was America's portion that was repealed. Madison concluded that Foster was "more disposed to play the diplomatist, than the conciliatory negotiator."19 The negotiations, which America had held out such high hopes for, were at an impasse.

During the last four months of 1811, Madison and Monroe wrote often of the likelihood of war. Monroe wrote his friend, Lord Holland, claiming he had entered office "with the best disposition to promote... an accommodation of all differences" which he claimed was also "unquestionably the wish of the President." Unfortunately, he continued, Britain only gave "evidence of a determined hostility" to American rights. Monroe accused Britain of trying "to push things to the worst" and implied that America now had its back to the wall. "War, dreadful as the alternative is, could not do us more injury and it would certainly be more 
honorable to the nation."20 For his part, Madison wrote John Quincy Adams, sounding much like Thomas Jefferson before him:

The question to be decided...by Congress, according to present appearances, simply is, whether all the trade to which the orders [in council] are and shall be applied, is to be abandoned, or the hostile operation of [the orders in council], be hostilely resisted. ${ }^{21}$

This was a dramatic turn about from the beginning of the year and shows just how great the disappointment in the failed negotiations was.

Madison's message at the opening of the new Congress was accordingly designed to convince the British ministers that the orders in council needed to be immediately revoked. In the speech Madison warned that, "The period is arrived which claims from the legislative guardians of the national rights a system of more ample provisions for maintaining them." As reasons for this he stressed the Orders though he also spoke of "other wrongs, so long and so loudly calling for" a remedy; a reference to impressment. Great Britain, he said, remained firm in "hostile inflexibility" and thus America had to put itself "into an armor and an attitude demanded by the crisis, and corresponding with the national spirit and expectation." He recommended Congress "augment the regular military, strengthen the state militias, build up the navy and secure and store arms and munitions."22 Despite the tone of the 
message it seems probable that even at this point Madison had no real desire for war but was instead simply trying to show the British that America meant business.

Pushed by war hawks, Congress passed the requested military legislation, though some members were still hesitant. ${ }^{23}$ Senator George $\mathrm{W}$. Campbell of Tennessee said America had "suffered national degradation too long, and endured insult and injury with too much patience." It was "extremely difficult to perceive how war can be avoided without degrading the national character still lower than it is."24 This was typical of the pro-war sentiments which often reflected upon a loss of national honor if action were not soon taken. Congressman Richard Johnson of Kentucky took this argument to its ultimate extreme when he claimed that America "must now oppose the further encroachment of Great Britain by war or formally annul the Declaration of Independence, and acknowledge ourselves her devoted colonies." 25 That this extreme, and somewhat ludicrous, statement was greeted with utter solemnity indicates how far towards war the pendulum had swung. A week later, Peter Porter, chair of the House Foreign Affairs Committee, recommended America go to war unless Britain rescinded the orders in council and agreed to "some satisfactory arrangements" on impressment. ${ }^{26}$ In the government, Rufus King was virtually alone in his belief that France had proceeded "to mislead a nation torn asunder 
by faction and blinded to her most important interests. "27 This was, however, a reiteration of the British point of view, which was unpopular in Washington at this time.

Impressment, as the statement by Peter Porter shows, was again becoming an issue, though this time because it helped fan the flames of war. Senator Felix Grundy claimed impressment was "over and above the unjust pretensions" of the orders in council. Henry clay said he could not...overlook the impressment of our seamen; an aggression upon which he never reflected without feelings of indignation, which would not allow him appropriate language to describe its enormity." 29 This was undoubtedly a true sentiment, but clay also knew that impressment was a volatile subject which could be used to stir general public indignation against England.

Realizing what was happening, foreign minister Foster wrote back to Lord Castlereagh, warning him that,

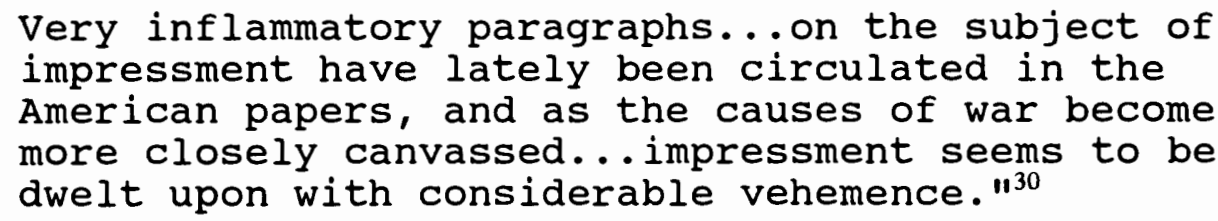

once more, there is no indication that this warning has taken into consideration. No action was taken upon it.

By early 1812 the Madison administration had all but given up on a peaceful solution. The President could see nothing in the conduct of Great Britain to indicate anything but "an adherence to her mad policy towards the 
United states." The combination of pro-war politics in Congress and lack of positive action from London helped contribute to Madison's new bleaker view of affairs. Then, on March 20, Minister Foster received new instructions. Unfortunately they changed nothing. "Honor and interest" required the orders in council to be "executed by force." American arms "must be met by British Cruizers according to the necessity of the case."32 With these words Britain's last opportunity to avert the oncoming crisis was lost. on receipt of these new orders Madison wrote to Jefferson that since Great Britain seemed to "prefer" war, America had "nothing left, therefore, but to make ready for it."33 Congress agreed and quickly passed a new embargo bill proposed by Henry clay. ${ }^{34}$ America was set on the road to war.

Monroe immediately began to stress impressment in an effort to underscore Britain's guilt, he described England as "[taking] the lead in the career of violence and injustice" and specified impressments. ${ }^{35}$ Again, the subject was used as a shortcut for getting the American public primed for the upcoming battle.

Foster received yet another set of instructions, this time from the new foreign secretary, Robert stewart, but these were as disappointing as the last set. Stewart claimed France had only made: 
some partial and insidious relaxations of [the Berlin and Milan Decrees]....as an encouragement to America to adopt a system beneficial to France and injurious to Great Britain.

Britain, despite assurance of war with America, was not going to budge from its original position. Madison believed that this position was that the orders in council would be repealed in relation to America if France did likewise. Now the foreign secretary claimed Britain had "never engaged to repeal those Orders, as affecting America alone, leaving them in force against other states."36 In other words, France would have to drop her Decrees against all nations before Britain would do likewise. Years later, Madison confided that it was at this point "no choice remained but between war and degradation."37 It is hard to argue with him. The only way for America to placate Great Britain would have been to convince France to drop her decrees against England, an action which would have gained France absolutely nothing. Avenues of escape seemed exhausted, there was only one road left to travel.

In his message of June 1, 1812, Madison recommended consideration of "whether the United States shall continue passive under these progressive usurpations and these accumulated wrongs." His list of grievances included the orders in Council and impressment. "Against this crying enormity which Great Britain would be so prompt to avenge if committed against herself, the United states have in 
vain exhausted remonstrances and expostulations." 38 The speech was the last little push needed. Not surprisingly, the House declared war on Great Britain on June $4 .{ }^{39}$

By emphasizing impressment the administration committed itself to a peace which settled the impressment issue. The committee on Foreign Relations indicated on June 3, that it made sense to do so. If the practice continued it would be "impossible for the United States to consider themselves an independent nation."40 The administration was ready to back those words to the hilt. Shortly after the senate declared war, Monroe sent the government's terms to Jonathan Russell, the chargé d'affairs in London. Before there could be peace Britain had to end impressment and restore all impressed American sailors. There could be no compromise. ${ }^{41}$ 
CHAPTER VIII

EPILOGUE, 1812-1818

Wartime diplomacy focused on impressment since it almost immediately became the only reason for the fighting. on June 23, 1812, just twelve days after America declared war, Britain's foreign secretary announced revocation of the orders in council.' It had been hoped this would convince America to cease hostilities but the Madison administration, perhaps flushed with their quick diplomatic victory, pushed for the repeal of impressment. ${ }^{2}$

Late in the fall of 1812, Monroe and Albert Gallatin drafted a bill to disallow the use of British sailors on American merchant ships. America would renounce the use of foreign sailors if their country of origin did the same for Americans. The measure would not affect foreign sailors already naturalized or in the process of naturalization before the end of the war. ${ }^{3}$ This bill passed both houses of Congress after debate, near the end of February, 1813.4 However, Lord Castlereagh, once again the foreign secretary, continued to stress the impossibility of renouncing impressment. ${ }^{5}$ He instructed his commissioners on July 28, 1814, "to ascertain whether the American negotiators have any specific measures to propose for 
obviating the alleged abuses of which they complain." Apparently the bill renouncing foreign sailors didn't count. Castlereagh then claimed his government would "weigh" American proposals "dispassionately...with a desire to conciliate." Yet he also emphasized that Britain could:

never recede from the principle of holding their own subjects to their duty of allegiance. The right of [impressment] can never be given up... in exchange for any municipal regulation. ${ }^{6}$

The American bill, then, was not specific enough.

Impressment remained a subject on which Britain would not give an inch.

It turned out they wouldn't have to. By the time these instructions were printed America had abandoned its sine qua non on impressment allowing its negotiators to accept a treaty silent on the issue. This was a dramatic reversal of the earlier position. In early 1813, Monroe had sent his instructions, demanding Britain abandon impressment at sea. To let the topic pass in silence would be to give up "all claim to neutral rights, and all other rights on the ocean." A month later Monroe added that a silence which trusted "to a mere understanding... would not be that security which the United States have a right to expect."7 Madison's attitude is unsurprising; at this point the war was young and America knew that Britain was in virtual isolation in its war with France. 
When, on June 24, 1814, President Madison asked the cabinet if they wanted to drop the sine qua non they were against it. Soon after news came of the firm stand Britain was taking on impressment as well as the collapse of Napoleon. On the 27 th the cabinet voted unanimously to accept silence on the issue. ${ }^{8}$ clearly their anger toward impressment did not extend to facing the British navy alone.

For their part, the American negotiators at Ghent, Albert Gallatin, John Quincy Adams, Henry Clay, James A. Bayard and Jonathan Russell, had always been in doubt about the wisdom of the sine qua non. Adams had argued that it would be best to "leave the question just where it is, saying nothing about it." 9 When the Americans learned that Britain agreed not to ask for positive approval of impressment they quickly let the entire issue drop. The peace treaty was signed on Christmas Eve, 1814, bypassing impressment entirely.

Yet the issue refused to die. Napoleon returned from exile on Elba in March, 1815. Britain, fearing a new Anglo-French war, again began pressing United states sailors, risking American wrath. In June, Castlereagh told Adams that "the Admiralty was now occupied in prescribing regulations for the naval officers which he hoped would prevent all cause of complaint."10 The British fear was that their practice would again lead to war, but such was 
not the case. When Madison proposed new legislation limiting the use of British sailors as a spur for negotiation, congress balked. In February, 1815 the matter was put off to the next session and in December it was allowed to die." It seems that America had never truly intended to go to war over impressment, but had found itself in the situation during the War of 1812 quite by accident. The majority of the members of the United states government were unwilling to make that mistake again.

Given this it is almost humorous that at this point Britain seemed finally to have a change of heart. Lord Liverpool, First Lord of the Treasury, feared that Britain would "never be engaged in a Maritime War with any Power without its leading to a war with the United States." still the Lord could see no acceptable substitute for "detention" as impressment was now called. America had "to admit the power of Detention under any circumstances." On this he felt "the success of any Negotiation will depend."12 This was a rather unlikely thing to expect to happen, and the British knew it. The Earl Bathurst, secretary of state for War and Colonies was sure that impressment would once again lead to war:

After what has passed the U. States cannot submit to the exercise of this right. It must predispose them against us in every war in which we shall be engaged, and it ensures to every European State, a certain Ally, in their hostility against us. ${ }^{13}$ 
Despite these fears the situation remained unchanged until 1818 .

On April 18, 1818, Richard Rush, the new envoy to Great Britain, on orders from Secretary of state John Quincy Adams, offered once more to exclude from United States service "all British subjects or seamen now in the United States...not heretofore naturalized" in return for renunciation of impressment at sea. ${ }^{14}$ Unbeknownst to the Americans, Lord Castlereagh already had cabinet approval for the plan. He had previously told them that impressment was "the Question of all others between the two Governments which has most operated to exasperate." If this agreement got Americans "to give adequate effect to their own policy...Gt. Britain will have not only gained her main object, but escape the danger of an American War."15 It seemed that the long and costly debate over impressment was finally at an end. Castlereagh revealed his cabinet approval, and, almost unbelievably, America remained unmoved. ${ }^{16}$
Why? Castlereagh had suggested that:
the reserve which the United States would require in favor of British subjects already Naturalized might be guarded by requiring a List of all Persons so claiming to be furnished within a time to be limited. ${ }^{17}$

This was exactly the kind of paperwork the states had been shying away from for years. The American administration refused Castlereagh's offer using the old argument that it 
might endanger sailors who could accidentally be omitted. "Upon impressment we have again completely failed." Richard Rush reported to ex-President Madison. "I fear sir, that it will only be left to some future administration to follow...the precedent of a remedy which you were forced at last to set." ${ }^{18}$ The negotiations then foundered and were soon after called off.

With this impressment virtually vanished from the diplomacy of the two countries, though it continued in practice. No future administration ever did follow Madison's path. America, it seems, after long argument and even armed combat, had finally learned to live with impressment. 
NOTES

Chapter one

${ }^{1}$ William Blackstone, Commentaries on the Laws of England in Four Books, vol. 1 (Philadelphia: Robert Bell, 1771), 418-419.

${ }^{2}$ Secretary of the Admiralty to Adm. Edward Vernon, October 11, 1745, quoted in Daniel Baugh, British Naval Administration in the Age of Walpole, (Princeton: Princeton University Press, 1965), 149, 150.

${ }^{3}$ Blackstone, 418 .

${ }^{4}$ Ibid., 369.

${ }^{5}$ Bond to Leeds, September 18, 1790, quoted in Charles R. Ritcheson, Aftermath of Revolution: British Policy Toward the United States, 1783-1795, (Dallas: Southern Methodist University Press, 1969), 216-217.

${ }^{6}$ Andre Limozin to Thomas Jefferson, September 26, 1787, Julian P. Boyd, ed., The Papers of Thomas Jefferson, vol. 12 (Princeton: Princeton University Press, 1955), 185 . 245 .

${ }^{7}$ Limozin to Jefferson, October 14, 1787, Ibid., 237.

${ }^{8} \mathrm{Jefferson}$ to Limozin, October 17,1787 , Ibid., 244-

9John Rutledge Jr. to Jefferson, May 6, 1790, Boyd, 16: 413 .

${ }^{10}$ Rutledge to Jefferson, May 12, 1790, Ibid., 426-428. 17: 489 .

${ }^{11}$ William Short to Jefferson, September 5, 1790, Boyd,

${ }^{12}$ Nathaniel Barrett to Jefferson, October 10,1790 , Ibid., 583 .

${ }^{13}$ David Humphreys to Jefferson, October 25,1790 , ibid. , 629-630. 


\section{8: 329 .}

${ }^{14} \mathrm{John}$ Brown Cutting to Jefferson, July 17, 1790, Boyd, 17: 670 .

${ }^{15}$ Joshua Johnson to Jefferson, November 2, 1790, Boyd,

${ }^{16}$ George Hammond to the President [George Washington], February 7, 1792, H.A. Washington, ed., The Writings of Thomas Jefferson, vol. 3 (Philadelphia: J.B. Lippincott \& Co., 1871), 334-335.

${ }^{17}$ Lord Grenville to John Jay, August 1, 1794, Henry P. Johnston, ed., The Correspondence and Public Papers of John Jay, vol. 4 (New York: Lenox Hill Pub. \& Dist. Co., 1970), 43.

${ }^{18}$ Henry Adams, The Formative Years, A History of the United states During the Administrations of Jefferson and Madison, vol. 1 (Boston: Houghton Mifflin Co., 1947), 254255 .

${ }^{19}$ Jefferson to Thomas Pinckney, March 16, 1793, Washington, 3: 525-526.

${ }^{20}$ Lord Hawkesbury [President of the Board of Trade] to Henry Wilckens, January 25, 1790, quoted in Ritcheson, 217.

${ }^{21}$ Hasmmond \#30 to Grenville, August 29, 1794, Public Records office [London], Foreign office 5/5 (hereafter referred to as FO).

\section{7: 670 .}

${ }^{22}$ Johnson to Jefferson, November 2, 1790, Boyd, ed.,

${ }^{23}$ Jefferson to Pinckney, June 11, 1792, Andrew A. Lipscomb, ed., The Writings of Thomas Jefferson, vol. 8 (Washington, D.C.: The Thomas Jefferson Memorial Association, 1903), 370-371.

${ }^{24}$ Pinckney to Jefferson, October 5, 1792, John Catanzariti, ed., The Papers of Thomas Jefferson, vol. 24 (Princeton: Princeton University Press, 1990), 442.

${ }^{25}$ Ritcheson, 382 .

${ }^{26}$ Annals of the Congress of the United States, (Washington, D.C.: Gales and Seaton, 1855), 3rd Congress, 1st session, 73 .

${ }^{27}$ Ibid. , 772 . 
${ }^{28}$ Ibid., 773 .

${ }^{29}$ Harold C. Syrett, ed., The Papers of Alexander Hamilton, vol. 16 (New York: Columbia University Press, 1977), 313-323.

${ }^{30}$ Jay to Grenville, July 23, 1794, Johnston, 4: 36.

${ }^{31}$ Jay to Grenville, July 30, 1794, Ibid., 40-41.

${ }^{32}$ Grenville to Jay, August 1, 1794, Ibid., 43-44.

${ }^{33}$ Grenville to Jay, July 9, 1796, Ibid., 221. 
NOTES

Chapter Two

${ }^{1}$ Ritcheson, 216 .

${ }^{2}$ Cobbett's Parliamentary Debates, vol. 2 (London: Cox and Bayles, 1804), 841 .

${ }^{3}$ Brian Lavery, Nelson's Navy, the Ships, Men and organization, 1793-1815, (Annapolis: Naval Institute Press, 1989), 16 .

${ }^{4}$ Roland G. Usher, "Royal Navy Impressment During the American Revolution," Mississippi Valley Historical Review 37 , no. 4 (March, 1951): 679.

${ }^{5}$ Lavery, 119 .

${ }^{6}$ Ibid.

${ }^{7}$ Ibid. , 122 .

${ }^{8}$ Admiralty Board Minutes, March 27, 1795, Public Records office [London], Admiralty Records 3/115 (hereafter referred to as Adm).

${ }^{9}$ April 8, 1795, Public Records office [London], Parliamentary Committees $2 / 142$.

${ }^{10}$ Admiral William Parker, General memorandum in force, June 24, 1795, enclosed in Captain George Tripp to Nepean, March 19, 1799, Adm 1/2599.

${ }^{11}$ Baugh, 148 .

${ }^{12}$ James Madison to Rufus King, July 24, 1801, Robert J. Brugger, ed., The Papers of James Madison, vol. 1

(Charlottesville: University Press of Virginia, 1986), 466-468.

${ }^{13}$ Thomas c. Hansard, ed., The Parliamentary Debates, vol. 24 (London: T.C. Hansard, 1812), 602 . 
${ }^{14}$ Douglass $c$. North, The Economic Growth of the United States, 1790 to 1860 , (New York: W.W. Norton \& Co. Inc., 1961), 36, 41 .

${ }^{15}$ Jackson T. Main, The social structure of

Revolutionary America, (Princeton: Princeton University Press, 1965), 74 . 670 .

${ }^{16}$ Johnson to Jefferson, November 2, 1790, Boyd, 17 :

${ }^{17}$ William Knox to Jefferson, April 19, 1791, Boyd, 12: 185 .

${ }^{18}$ Baugh, 148, 229.

${ }^{19}$ Albert Gallatin to Jefferson, April 13/16, 1807, Thomas Jefferson Papers, (Washington, D.C.: Library of Congress, 1974), Series 1, Reel 38 . 195.

${ }^{20}$ Jefferson to Gallatin, April 21, 1807, Lipscomb, 11:

${ }^{21}$ Admiral Hyde Parker to Liston, Private, April 12, 1797, Adm 1/248. 
NOTES

Chapter Three

'John Adams to Pickering, June 7, 1799, Charles F. Adams, ed., The Works of John Adams, vol. 8 (Boston: Little, Brown \& Co., 1853), 656.

'Jefferson to Robert R. Livingston, September 9, 1801, Washington, 4: 408-409.

${ }^{3}$ Frank A. Updyke, The Diplomacy of the War of 1812 , (Gloucester: Peter Smith, 1965), 71; Thomas G. Paterson, J. Gary Clifford and Kenneth J. Hagan, American Foreign Policy, A History to 1914, (Lexington: D.C. Heath \& Co., 1988), 48 .

${ }^{4} J a y$ to President Washington, September 3, 1795, Johnston 4: 189 .

${ }^{5}$ Annals, 4 th Congress, 1st session, 350.

${ }^{6}$ Ibid. , 372 .

${ }^{7}$ Ibid. , 400 .

${ }^{8}$ Ibid. , 802, 820.

${ }^{9}$ Ibid., 1423 .

${ }^{10}$ Ibid. , 806.

${ }^{11}$ Ibid. , 73 .

${ }^{12}$ Ibid. , 62, 63, 65-67, 72, 73.

${ }^{13}$ Ibid. , 1498 .

${ }^{14}$ Annals, 4th Congress, 2nd session, 1691.

${ }^{15}$ Ibid. , 2335 .

${ }^{16}$ Ibid. , 1575, 2335. 
${ }^{17}$ Madison to James Monroe, July 25, 1801, James Madison Papers, (Washington, D.C.: Library of Congress, 1964), Series 1, Reel 7 .

${ }^{18} \mathrm{King}$, memorandum, conversation with Lord Grenville, August 10, 1796, Charles R. King, ed., The Life and Correspondence of Rufus King, (New York: Putnam's, 1895), 616-620.

${ }^{19}$ Hansard, Parliamentary Debates, 24: 603. $83 / 2204$.

${ }^{20} \mathrm{Sir}$ William Scott to Grenville, July 11, 1796, Fo

${ }^{21}$ King to Jonathan Dayton, December 6, 1796 , private, quoted in Robert Ernst, Rufus King, American Federalist, (Chapel Hill, University of North Carolina Press, 1968), 236 .

${ }^{22}$ Grenville to King, November 30, 1796, March 27, 1797, Walter Lowrie, ed., American state Papers, Foreign

Relations, vol. 2 (washington, D.C.: Gales \& Seaton, 1832, 149 , 150. (Hereafter referred to as A.S.P.F.R.).

${ }^{23}$ King to Dayton, December 6, 1796, private, quoted in Ernst, 236.

${ }^{24}$ Grenville to the Lords of the Admiralty, August 28 , 1797, Adm 1/4173.

${ }^{25}$ Jefferson to Madison, September 2, 1806, Madison Papers, Series 1, Reel 9.

${ }^{26}$ Annals, 5th Congress, vol. 1, 763 .

${ }^{27}$ Ibid. , 1035 .

${ }^{28}$ Ibid. , 2546 .

${ }^{29}$ Ibid. , 2574-2576.

${ }^{30}$ Ibid. , 2234, 2240 .

${ }^{31}$ United States Statutes At Large, vol. 2 (Washington, D.C.: U.S. Government Printing Office, 1845), 203-205. 239 .

${ }^{32}$ King to Pickering, July 15, 1799, quoted in Ernst,

${ }^{33}$ Annals, 6th Congress, 1st session, 730 . 
${ }^{34}$ Lenox to the Secretary of State, March 10, 1802, Annals, 7th Congress, 2nd session, 924-925.

${ }^{35}$ Lenox to Nepean, October 23, 1801, Ibid., 926.

${ }^{36}$ William Marsden to Lenox, October 26, 1801, Ibid., 926-927.

${ }^{37}$ Aurora (Philadelphia), July 19, 1803, quoted in Scott Thomas Jackson, Impressment and Anglo-American Discord, 1787-1818, (Ann Arbor: University of Michigan Press, 1976), 156 .

${ }^{38}$ Independent Chronicle (Boston), September 5, 1803, quoted in Ibid.

${ }^{39} \mathrm{Salem} \mathrm{Register}$ (Salem), August 4, 1803, quoted in Ibid. , 156-157.

${ }^{40} \mathrm{King}$ to Madison, July (no date), 1803, quoted in Ernst, 240 .

${ }^{41}$ Madison to Monroe, October 10, 1803, James Madison Papers, Series 1, Reel 8 .

${ }^{42}$ Thomas Jefferson, Third Annual Message, October 17 , 1803, Lipscomb, 3: 358.

${ }^{43}$ Jefferson to Madison, July 31, 1803, Madison Papers, Series 1, Reel 7 .

${ }^{44}$ Madison to Monroe, October 10,1803 , Ibid., Series 1, Reel 8.

${ }^{45}$ Cobbett's, $1: 45$.

${ }^{46}$ Ibid. , 1175.

${ }^{47}$ Henry Adams, Formative Years, 1: 271. 
NOTES

Chapter Four

${ }^{1}$ Hawkesbury to Anthony Merry, September 16, 1803, nos. 1-4, Bernard Mayo, ed., Instructions to the British Ministers to the United States, 1791-1812, American Historical Association Annual Report for 1936, vol. 3 (Washington, D.C.: U.S. Government Printing office, 1941), 197-201.

${ }^{2}$ James F. Zimmerman, Impressment of American Seamen, (Port Washington: Kennikat Press, 1966 [1912]), 260-261.

${ }^{3}$ Annals, 8th Congress, 1st session, 106.

${ }^{4}$ Adams, Formative Years, 259.

${ }^{5}$ Mayo, ed., Instructions, 3: 197-201.

${ }^{6}$ Merry to Hawkesbury, December 6, 1803, nos. 1, 2; Merry to Hawkesbury, December 31, 1803, no. 6, quoted in Malcom Lester, Anthony Merry Redivivus: A Reappraisal of the British Minister to the United States, 1803-1806, (Charlottesville: University Press of Virginia, 1978), 49.

${ }^{7}$ Annals, 8th Congress, 1st session, 80 .

${ }^{8}$ Ibid. , 210

${ }^{9}$ George Erving to Monroe, November 5, 1803, enclosed in Monroe to Madison, December 15, 1803, Madison Papers, Series 1, Reel 8 .

${ }^{10}$ Annals, 8 th Congress, 1st session, 214 .

${ }^{11}$ Ibid. , 232 .

${ }^{12}$ Merry to Hawkesbury, January 20,1804 , no. 12 , quoted in Lester, 50.

${ }^{13}$ Jefferson to Thomas Paine, March 18, 1801; Jefferson to Short, October 3, 1801, Lipscomb, 10: 223, 287.

${ }^{14}$ Annals, 8th Congress, 1st session, 264. 
${ }^{15}$ Thomas Barclay to Admiral Sir Andrew Mitchell, November 21, 1803, George L. Rives, ed., Selections from the Correspondence of Thomas Barclay, (New York: Harper \& Brothers, 1894), 154 .

${ }^{16}$ Merry to Hawkesbury, no. 30, April 29, 1804, quoted in Lester, 51 .

${ }^{17}$ Cobbett's, 2: 841 .

${ }^{18}$ Ibid. , Ixxiv.

${ }^{19}$ Barclay to Captain William Bradley, June 19, 1804, Rives, 165-166.

${ }^{20}$ Merry to Hawkesbury, July 2, 1804 , no. 36, quoted in Lester, 53 .

${ }^{21}$ Merry to Madison, August 15, 1804, enclosure in Merry to Harrowby, September 4, 1804, no. 45, quoted in Ibid., 55 .

${ }^{22}$ Madison to Jefferson, August 28, 1804, Thomas Jefferson Papers, Series 1, Reel 31.

${ }^{23}$ Harrowby to Merry, November 7, 1804, no. 3, Instructions, 208-211.

${ }^{24}$ Monroe to Madison, April 26, 184 ; Monroe to Madison, May 3, 1804, James Monroe Papers, (Washington, D.C.: Library of Congress, 1969), Series 1, Reel 3.

${ }^{25}$ Adams, Formative Years, 310 .

${ }^{26}$ Monroe to Madison, June 3, 1804, quoted in Jackson, 172-173.

${ }^{27}$ Monroe to Madison, August 7, 1804, Ibid., 175.

${ }^{28}$ Monroe to Madison, September 8, 1804, Ibid., 179.

${ }^{29} \mathrm{Sir}$ Walter Scott to Harrowby, September 2, 1804, FO 5/104.

${ }^{30}$ Monroe to Madison, october 3, 1804, quoted in Jackson, 182 .

${ }^{31}$ Annals, 8th Congress, 1st session, 867.

${ }^{32}$ Ibid. , 1006. 
${ }^{33}$ Madison to Merry, March 28, 1805, enclosure in Merry to Harrowby, March 30, 1805, no. 17, quoted in Lester, 57.

${ }^{34}$ Annals, 8th Congress, 2nd session, 1694, 1697.

${ }^{35}$ Merry to Madison, April 12, 1805, quoted in Lester, 57-58.

${ }^{36}$ Adams, Formative Years, 311.

${ }^{37}$ Cobbett's, 5: 558 .

${ }^{38}$ Monroe to Madison, August 6, 1805, quoted in Jackson, 190 .

${ }^{39}$ Cobbett's, $4: 145$.

${ }^{40}$ Monroe to Madison, October 18, 1805, quoted in Jackson, 191.

${ }^{41}$ Mulgrave to Prime Minister William Pitt, October 12, 1805, quoted in Ibid., 191-192.

${ }^{42}$ Monroe to Madison, December 11, 1805; Monroe to Mulgrave, November 29, 1805, quoted in Ibid., 192. 
NOTES

Chapter Five

${ }^{1}$ Phineas Bond to Mulgrave, December 3, 1805, contained in Merry \#50 to Mulgrave, December 2, 1805, quoted in Lester, 71-72.

${ }^{2}$ Madison to Jefferson, September 14, 1805, Thomas Jefferson Papers, Series 1, Reel 31.

${ }^{3}$ Madison to Monroe, March 6, 1805, quoted in Irving Brant, James Madison: Secretary of State, 1801-1809,

(Indianapolis: The Bobbs-Merrill Co., Inc., 1953), 293.

${ }^{4}$ Monroe to Jefferson, September 26, 1805, quoted in stanislaus M. Hamilton, ed., The Writings of James Monroe, vol. 4 (New York: G.P. Putnam's Sons, 1900), 336-337.

${ }^{5}$ Washington, 8: 48 .

${ }^{6}$ Dumas Malone, Jefferson and His Time, vol. 5, Jefferson the President: Second Term, 1805-1809, (Boston: Little, Brown \& Co., 1974), 69.

${ }^{7}$ Monroe \#35 to Madison, October 18, 1805, quoted in, Annals, 10th Congress, 1st session, 2: 2422 .

${ }^{8}$ Madison to Monroe, private, January 13, 1806, James Madison Papers.

${ }^{9}$ A.S.P.F.R., 2: $772-773$.

10Malone, 101 .

${ }^{11}$ Charles F. Adams, ed., The Memoirs of John Quincy Adams, vol. 1 (Freeport: Books for Libraries Press, 1969, 386 .

${ }^{12}$ Ibid. , 395.

${ }^{13}$ Annals, 9 th Congress, 1st session, 412-413.

${ }^{14}$ Adams, Memoirs, 1: 395-397. 
${ }^{15}$ Samuel Flagg Bemis, John Quincy Adams and the Foundations of American Foreign Policy, (New York: Alfred A. Knopf, 1956), 136-137; Adams, Memoirs, 1: 395-397.

${ }^{16}$ Annals, 9 th Congress, 1st session, 91, 112 .

${ }^{17}$ Ibid. , 442 .

${ }^{18}$ Ibid. , 553 .

${ }^{19}$ Ibid., $458-460$.

${ }^{20}$ Ibid. , $450-451$.

${ }^{21}$ Adams, Memoirs, 1: 408 .

${ }^{22}$ Ibid. , 415.

${ }^{23}$ Annals, 9 th Congress, 1st session, 86 .

${ }^{24}$ Madison to Monroe, private, March 11, 1806, Madison Papers.

${ }^{25}$ Jefferson to Thomas Cooper, February 18, 1806, Thomas Jefferson Papers, Series 1, Reel 38.

${ }^{26}$ Annals, 9th Congress, 1st session, 537-769 passim.

${ }^{27}$ Ibid., 769-832 passim.

${ }^{28}$ Ibid. , 240, 1259-1260.

${ }^{29}$ Ibid. , 412-413, 659-660.

${ }^{30}$ Ibid. , 555, 558-590, 643, 728 .

${ }^{31}$ Ibid. , 673-674.

${ }^{32} \mathrm{King}$ to $\mathrm{Sir}$ Francis Baring, September 30, 1806, quoted in Ernst, 302 .

${ }^{33}$ Annals, 9th Congress, 1st session, 539-541, 642, 708, $732-733,766,781,808$.

${ }^{34}$ Pinckney to Jefferson, March 13, 1806, Thomas Jefferson Papers, Series 1, Reel 38.

${ }^{35}$ Monroe \#41 to Madison, February 12, 1806, quoted in Annals, 10th Congress, 1st session, 2: 2434-2436. 
${ }^{36}$ Jefferson to Levi Lincoln, June 25, 1806, Jefferson Papers, Series 1, Reel 38 .

${ }^{37} \mathrm{Gaillard} H u n t$, ed. , The Writings of James Madison,

vol. 7 (New York: G.P. Putnam's Sons, 1908), 377.

${ }^{38}$ John Tyler to Jefferson, March 25, 1806, Thomas Jefferson Papers, Series 1, Reel 38 .

${ }^{39}$ Wilson Cary Nicholas to Jefferson, April 2, 1806, Thomas Jefferson Papers, Series 1, Reel 38 .

${ }^{40}$ Monroe to Charles James Fox, February 25, 1806, quoted in Annals, 10th Congress, 1st session, 2: 24372440 .

${ }^{41}$ Admiralty Records, Adm 8/90-93.

${ }^{42}$ Bradford Perkins, Prologue to War: England and the United States, 1805-1812 (Berkeley: University of California Press, 1961), 122.

${ }^{43}$ Jefferson to Monroe, October 26, 1806, James Monroe Papers, Series 1, Reel 3 .

${ }^{44}$ Perkins, 122 .

${ }^{45}$ Monroe \#45 to Madison, April 18, 1806 , quoted in Annals, 10th Congress, 1st session, 2: 2445.

${ }^{46}$ Monroe and Pinckney \#5 to Madison, September 11, 1806, A.S.P.F.R., 3: 133 .

${ }^{47}$ Ibid. , $3: 134$.

${ }^{48}$ Anthony Steel, "Impressment in the Monroe-Pinckney Negotiation, 1806-1807", American Historical Review, LVII (1951-1952), (New York: The Macmillan Co., 1952), 356-358.

${ }^{49}$ Monroe and Pinckney \#6 to Madison, November 11, 1806 , A.S.P.F.R., 3: 137-140.

${ }^{50}$ Entry of November 4,1806 , Journal of Negotiations, Adm 80/117. 140 .

${ }^{51}$ Monroe and Pinckney, November 8, 1806, A.S.P.F.R., 3 :

${ }^{52}$ Perkins, $130-133$ 
${ }^{53}$ Madison to Monroe and Pinckney, February 3, 1807, Annals, 10th Congress, 1st session, 2: 2539-2545.

${ }^{54}$ Erskine \#8 to Lord Howick, March 6/10, 1807, FO 5/52.

${ }^{55}$ Adams, Memoirs, 1: 465-466. 
NOTES

\section{Chapter Six}

${ }^{1}$ Cabinet meetings of March 17, April 4, 1807, Paul L. Ford, ed., The Writings of Thomas Jefferson, vol. 1 (New York: Capital Editions, 1892), 323-324.

${ }^{2}$ Gallatin to Thomas Jefferson, April 13, 1807, Thomas Jefferson Papers, Series 1, Reel 39.

${ }^{3}$ Madison to Jefferson, April 17/20, 1807, Thomas Jefferson Papers, Series 1, Reel 39.

${ }^{4} J e f f e r s o n$ to Madison, April 25, 1807, James Madison Papers, Series 1, Reel 9.

${ }^{5}$ Jefferson to Madison, April 21, 1807, Washington, 5: $69-70$.

${ }^{6}$ Madison to Jefferson, May 4, 1807, Thomas Jefferson Papers, Series 1, Reel 39.

${ }^{7}$ Madison to Monroe and Pinckney, May 20, 1807, quoted in Annals, 10th Congress, 1st session, 2: 2588-2589.

${ }^{8}$ Erskine to Madison, January 4, 1807, Madison to David Erskine, January 7, 1807, enclosed in Erskine \#3 to Charles Grey, Viscount Howick, February 1, 1807, FO 5/52.

${ }^{9}$ Erskine \#7 to Howick, February 2, 1807, FO 5/52.

${ }^{10}$ Henry Adams, Formative Years, vol. 4: 1-2.

${ }^{11}$ Parker to Hamilton, March 14,1807 , FO 5/52.

${ }^{12}$ Robert Smith to James Barron, April 16, 1807, Barron to Smith, April 7, 1807, FO 5/54.

${ }^{13}$ J.E. Douglas to Berkeley, April 15, 1807, Adm 1/497.

${ }^{14}$ Berkeley to Marsden, March 23, April 28, 1807, Adm $1 / 497$.

${ }^{15}$ Berekeley to Marsden, May 31, 1807, Adm 1/497. 
${ }^{16}$ Henry Adams, History of the United States of America During the Second Administration of Thomas Jefferson, vol. 4 (New York: Charles Scribner's Sons, 1893), 9-20.

${ }^{17}$ Adams, History, $4:$ 27-28.

${ }^{18}$ Perkins, $142-143$.

${ }^{19}$ Jefferson to Governor William Cabell, July 29, 1807, Ford, 9: 87-88.

${ }^{20}$ Cabinet meeting of July 2, 1807, Ford, 1: 410-411.

${ }^{21}$ Samuel Smith to Madison, June 30, 1807, Thomas Jefferson Papers, Series 1, Reel 39.

${ }^{22} \mathrm{Nicholas}$ to Jefferson, July 7, 1807, Ibid.

${ }^{23}$ James G. Jackson to Madison, July 5, 1807, James Madison Papers, Series 1, Reel 9.

${ }^{24}$ Jefferson to George clinton, July 6, 1807, to Thomas Cooper, July 9, 1807, to Barnabas Bidwell, July 11, 1807, Washington, 5: 116, 121, 126. 274

${ }^{25}$ Enquirer (Richmond), July 8, 1807, quoted in Jackson,

${ }^{26}$ Jefferson to Harry Dearborn, July 7, 1807, Washington, 6: 117 .

${ }^{27}$ Jefferson to Bidwell, July 11, 1807, to Dearborn, July 13, 1807, to Dearborn, July 17, 1807, Ibid., 125-127, 135.

${ }^{28}$ Madison to Monroe, July 6, 1807, Annals, 10th Congress, 1st session, 2: 2620 .

${ }^{29} \mathrm{Gallatin}$ to Madison, August 15, 1807, James Madison Papers, Series 1, Reel 9.

${ }^{30}$ George Canning to Monroe, July 25, 1807, Annals, 10th Congress, 1st session, 2: 2627.

${ }^{31}$ Monroe to Canning, July 27, 1807, Ibid., 2628.

${ }^{32}$ Monroe to Canning, July 29, 1807, Ibid., 2629.

${ }^{33}$ Canning to Monroe, August 3, 1807, Monroe to Madison, August 4, 1807, Ibid., 2629-2630. 
${ }^{34}$ Monroe and Pinckney to Madison, october 22, 1807, Ibid. , 2651-2652.

${ }^{35}$ Monroe to Madison, September 16, 1807, Ibid., 2633-2636.

${ }^{36}$ Monroe to Canning, September 7, 1807, Ibid., 2633-2634.

${ }^{37}$ Canning to Monroe, September 23, 1807, Ibid., $2657-2663$.

${ }^{38}$ Monroe to Pinckney and Madison, october 22, 1807, Ibid. , 2651-2652.

${ }^{39}$ Jefferson to Robert Smith [Secretary of the Navy], September 18, 1807, Washington, 5: 196.

${ }^{40}$ Lipscomb , 9: 145-166.

${ }^{41}$ National Intelligencer, October 26,1807 , quoted in Jackson, 304 .

${ }^{42}$ Adams, History, 4: 133, 166, 168-170.

${ }^{43}$ A.S.P.F.R., 3: 25; Perkins, 153-156. 
NOTES

\section{Chapter Seven}

'Jefferson to William Lyman, April 30, 1808, Thomas Jefferson Papers, Series 1, Reel 40 .

${ }^{2}$ London Consulate Records, Registers of Impressed Seamen, 1803-1812, Department of State Archives, National Archives, RG-84.

${ }^{3}$ George Henry Rose to canning, confidential, March 22 , 1808 , FO $5 / 56$.

${ }^{4}$ Gallatin to Erskine, August 13, 1809, quoted in Hansard, 17: clxxiv. FO $5 / 56$.

${ }^{5}$ Brant, 404-418; Rose \#4 to Canning, January 18, 1808,

6Madison to Pinckney, April 4, 1808, quoted in Annals, 10th Congress, 1st session, 2: 1603-1605.

${ }^{7}$ Adams, History, 4: 168-170.

${ }^{8}$ Erskine \#31 to Canning, December 23, 1807, FO 5/52.

${ }^{9}$ Zimmerman, $171-174$.

${ }^{10}$ Annals, 11th Congress, 1st \& 2nd sessions, 2 :

2582-2584; Annals, 11th Congress, 3rd session, 1338-1339.

${ }^{11}$ Madison to Jefferson, March 18, 1811, James Madison Papers, Series 1, Reel 13.

${ }^{12}$ Monroe to Dr. Charles Everett, April 28, 1811, Hamilton, 5: 187 .

${ }^{13}$ Annals, 11th Congress, 3rd session, 1035.

${ }^{14} \mathrm{John}$ P. Morier to Adm. Sir Herbert Sawyer, May 20, 1811, FO 5/74.

${ }^{15}$ Monroe to Foster, July 23, 1811, James Monroe Papers, Series 1, Reel 4 . 
${ }^{16}$ Marquis of Wellesley to Foster \#8, secret, April, 1811, Mayo, 3: 318-324.

${ }^{17}$ Perkins, 275-281; Foster to Monroe, July 3, 16, 1811, A.S.P.F.R., 3: 435-439.

${ }^{18}$ Monroe to Foster, July 23, 1811, Foster to Monroe, July 24, 1811, Ibid., 439-442.

${ }^{19}$ Madison to Monroe, July 2, 1811 (Misdate certain), James Monroe Papers, Series 1, Reel 4.

${ }^{20}$ Monroe to Holland, fall, 1811, Hamilton, 5: 191-192.

${ }^{21}$ Madison to John Quincy Adams, November 15, 1811, James Madison Papers, Series 1, Reel 13.

${ }^{22}$ Madison's Third Annual Message, November 5, 1811, Hunt, 8: 158-165.

${ }^{23}$ Perkins, 356-366.

${ }^{24}$ George Washington Campbell to Andrew Jackson, December 24, 1811, Andrew Jackson Papers, (Washington, D.C.: Library of Congress, 1968).

${ }^{25}$ Annals, 12th Congress, 1st session, 1: 457.

${ }^{26}$ Ibid. , 417 .

${ }^{27}$ King to [Peter b. Porter], December 10, 1811, Private, quoted in Ernst, 312.

${ }^{28}$ Annals, 12th Congress, 1st session, 1: 425 .

${ }^{29}$ Ibid. , 600 .

${ }^{30}$ Foster to Castlereagh, April 23, 1812, quoted in Hansard, 10: 372 .

31 Madison to Jefferson, February 7, 1812, James Madison Papers, Series 1, Reel 13.

${ }^{32}$ Wellesley \#1, January 28, 1812, Mayo, 3: 340-344.

${ }^{33}$ Madison to Jefferson, April 3, 1812, James Madison Papers, Series 1, Reel 13.

${ }^{34}$ Annals, 12 th Congress, 1st session, 1: 187-189, 2 : 1587-1598. 
${ }^{35}$ Brant, $\quad 434-436$.

${ }^{36}$ Foser \#41 to Castlereagh, June 6, 1812, \#42, June 8, 1812 , FO $5 / 86$.

${ }^{37}$ Madison to Henry Wheaton, February 26, 27, 1827, James Madison Papers, Series 1, Reel 21.

${ }^{38}$ Madison, message, June 1, 1812, Hunt, 8: 192-200.

${ }^{39}$ Perkins, $406-410$.

${ }^{40}$ Report of the House Committee on Foreign Relations, June 3, 1812, A.S.P.F.R., 3: 569.

${ }^{41}$ Monroe to Jonathan Russell, June 26, 1812, Mayo, 3: 412. 
NOTES

Chapter Eight

${ }^{1}$ Castlereagh to Russell, June 23, 1812, Irish University Press Area studies Series, British Parliamentary Papers, United States of America, vol. 10 (Shannon, Ireland: Irish University Press, 1972), 127.

${ }^{2}$ Russell to Castlereagh, August 24, 1812, Ibid., 129.

${ }^{3}$ Bradford Perkins, Castlereagh and Adams: England and the United States, 1812-1823, (Berkeley: University of California Press, 1964), 51-52.

${ }^{4}$ Annals, 12th Congress, 2nd session, 932-940.

${ }^{5}$ Perkins, Castlereagh, 52-53; Castlereagh to Russell, August 29, 1812, Parliamentary Papers, 10: 131 . $5 / 101$.

${ }^{6}$ Castlereagh to commissioners, July 28, 1814, Fo

${ }^{7}$ Monroe to Gallatin, John Quincy Adams and James A. Bayard, April 15, 1813, Monroe to Gallatin, May 5, 1813, James Monroe Papers, Series 1, Reel 5. 280-281.

${ }^{8}$ Cabinet Memoranda, June 23, 24, 27, 1814, Hunt, 8:

${ }^{9} \mathrm{Gallatin}$ to Monroe, private, May 2, 8, 1813, Bayard to Monroe, May 5, 1813, James Monroe Papers, Series 1, Reel 5; Adams to John Adams, February 17, 1814, worthington C. Ford, ed., The Writings of John Quincy Adams, (New York: Greenwood Press, 1968), 5: 21-22.

${ }^{10}$ Perkins, Castlereagh, 161-162.

${ }^{11}$ Annals, 13th Congress, 3rd session, 275-278; A.S.P.F.R., $4:$ 1-4.

${ }^{12}$ Liverpool to Castlereagh, private and confidential, september 26, 1816, FO 5/119.

${ }^{13}$ Earl Bathurst, memorandum, october 6, 1816, Fo 5/119. 
${ }^{14}$ Perkins, Castlereagh, 256.

${ }^{15}$ Ibid. , 257, n. 39.

${ }^{16}$ Ibid. , 268-269.

${ }^{17}$ Unsigned Foreign Office memorandum, n. d., FO 5/137.

${ }^{18}$ perkins, Castlereagh, 271. 
WORKS CITED

\section{PRIMARY SOURCES}

American State Papers, Foreign Relations, vols. 2-4, Washington, D.C.: Gales \& Seaton, 1832 .

Annals of the congress of the United States. 3rd Cong., 1st sess., 4th Cong., 2nd sess., 5th Cong., vol. 1, 6th Cong., 1st sess., 7th Cong., 2nd sess., 8th Cong., 1st sess., 8th Cong., 2nd sess., 9th Cong., 1st sess., 10th Cong., 1st sess., 11th Cong., 1st \& 2nd sess., 11th Cong., 3rd sess., 12th Cong., 1st sess., 12th Cong., 2nd sess., 13th cong., 3rd sess. Washington, D.C.: Gales \& Seaton, 1849-1853.

Boyd, Julian P., ed. The Papers of Thomas Jefferson. vols. 12, 16-18. Princeton: Princeton University Press, 1955-1971.

British Parliamentary Papers, United States of America. Irish University Press Area Studies Series, vols. 10, 12. Shannon, Ireland: Irish University Press, 1972.

Brugger, Robert J., ed. The Papers of James Madison. vol. 1. Charlottesville: University Press of Virginia, 1986.

Catanzariti, John, ed. The Paper's of Thomas Jefferson. vol. 24. Princeton: Princeton University Press, 1990 .

Cobbett's Parliamentary Debates. vols. 1, 2, 4, 5 . London: Cox \& Bayles, 1804-1805.

Ford, Paul L., ed. The Writings of Thomas Jefferson. vols. 1, 9. New York: Capital Editions, 1892-1899.

Ford, Worthington $C$., ed. The Writings of John Quincy Adams. vol. 5. New York: Greenwood Press, 1968.

Hamilton, Stanislaus M., ed. The Writings of James Monroe. vols. 4, 5. New York: G.P. Putnam's Sons, 1900-1901. 
Hansard's Parliamentary Debates. vols. 10, 24 . London: T.C. Hansard, 1808, 1812 .

Hunt, Gaillard, ed. The Writings of James Madison. vols. 7, 8. New York: G.P. Putnam's Sons, 1908.

Andrew Jackson Papers. Washington, D.C.: Library of Congress, 1968.

Thomas Jefferson Papers. Washington, D.C.: Library of Congress, 1974 .

Johnston, Henry P., ed. The correspondence and Public papers of John Jay. vol. 4. New York: Lenox Hill Pub. \& Dist. Co., 1970.

King, Charles R., ed. the Life and Correspondence of Rufus king. New York: G.P. Putnam's Sons, 1895.

Lipscomb, Andrew A., ed. The Writings of Thomas Jefferson. vols. 3, 8-11. Washington, D.C.: The Thomas Jefferson Memorial Association, 1903-1904.

London Consulate Records. Registers of Impressed Seamen, 1803-1812. Department of State Archives. National Archives, RG-84.

James Madison Papers. Washington, D.C.: Library of Congress, 1964 .

Mayo, Bernard, ed. Instructions to the British Ministers to the United States, 1791-1812. American Historical Association Annual Report for 1936, vol. 3. Washington, D.C.: U.S. Government Printing office, 1941 .

James Monroe Papers. Washington, D.C.: Library of Congress, 1969.

Public Records office [London]. Admiralty Records 1/248, $497,2599,4173$. 3/115. 80/117.

Public Records office [London]. Foreign office 5/5, 52, $54,56,74,86,101,104,119,137.8 / 90-93$. $83 / 2204$.

Public Records office [London]. Parliamentary Committees $2 / 142$. 
Rives, George L., ed. Selections From the correspondence of Thomas Barclay. New York: Harper \& Brothers, 1894 .

Syrett, Harold C., ed. The Papers of Alexander Hamilton. vol. 16. New York: Columbia University Press, 1977.

United States Statutes at Large. vol. 2. Washington, D.C.: U.S. Government Printing office, 1845.

Washington, H.A., ed. The Writings of Thomas Jefferson. vols. 3-6, 8. Philadelphia: J.B. Lippincott Co., 1871 . 
WORKS CITED

SECONDARY SOURCES

Adams, Charles F., ed. The Memoirs of John Quincy Adams. vol. 1. Freeport: Books for Libraries Press, 1969.

--. The Works of John Adams. vol. 8. Boston: Little, Brown \& Co., 1853.

Adams, Henry. The Formative Years, A History of the United states During the Administrations of Jefferson and Madison. vols. 1,4. Boston: Houghton Miffin Co., 1974 .

-- History of the United states of America During the Second Administration of Thomas Jefferson. vol. 4. New York: Charles Scribner's Sons, 1893.

Aurora (Philadelphia). July 19, 1803. Quoted in scott Thomas Jackson. Impressment and Anglo-American Discord, 1787-1818, 156. Ann Arbor: University of Michigan Press, 1976.

Baugh, Daniel. British Naval Administration in the Age of Walpole. Princeton: Princeton University Press, 1965.

Bemis, Samuel Flagg. John Quincy Adams and the Foundations of American Foreign Policy. New York: Alfred A. Knopf, 1956.

Blackstone, William. Commentaries on the Laws of England in Four Books. vol. 1. Philadelphia: Robert Bell, 1771 .

Brant, Irving. James Madison: Secretary of State, 1801-1809. Indianapolis: The Bobbs-Merrill Co. Inc. 1953 .

Enquirer (Richmond). July 8, 1807. Quoted in Jackson, 274 .

Ernst, Robert. Rufus King, American Federalist. Chapel Hill: University of North Carolina Press, 1968. 
Independent Chronicle (Boston). September 5, 1803. Quoted in Jackson, 156.

Jackson, Scott Thomas. Impressment and Anqlo-American Discord, 1787-1818. Ann Arbor: University of Michigan Press, 1976.

Lavery, Brian. Nelson's Navy, the Ships, Men and organization, 1793-1815. Annapolis: Naval Institute Press, 1989.

Lester, Malcom. Anthony Merry Redivivus: A Reappraisal of the British Minister to the United States, 1803-1806. Charlottesville: University Press of Virginia, 1978.

Main, Jackson T. The social structure of Revolutionary America. Princeton: Princeton University Press, 1965.

Malone, Dumas. Jefferson and His Time. Vol. 5, Jefferson the President: Second Term, 1805-1809. Boston: Little, Brown \& Co., 1974.

National Intelligencer. October 26, 1807 . Quoted in Jackson, 304 .

North, Douglass c. The Economic Growth of the United States, 1790 to 1860 . New York: W.W. Norton \& Co. Inc. , 1961.

Paterson, Thomas G., Gary Clifford and Kenneth J. Hagan. American Foreign Policy: A History to 1914. Lexington: D.C. Heath \& Co., 1988.

Perkins, Bradford. Castlereagh and Adams: England and the United States, 1812-1823. Berkeley: University of California Press, 1964 .

--- Prologue to War: England and the United States, 1805-1812. Berkeley: University of California Press, 1961 .

Ritcheson, Charles R. Aftermath of Revolution: British Policy Toward the United States, 1783-1795. Dallas: Southern Methodist University Press, 1965.

Salem Register (Salem). August 4, 1803. Quoted in Jackson, 156-157. 
Steel, Anthony. "Impressment in the Monroe-Pinckney Negotiation, 1806-1807." American Historical Review $57,(1951-1952): 356-358$.

Updyke, Frank A. The Diplomacy of the War of 1812. Glouchester: Peter Smith, 1965.

Usher, Roland G. "Royal Navy Impressment During the American Revolution." Mississippi Valley Historical Review 37, no. 4 (March 1951): 679.

Zimmerman, James F. Impressment of American Seamen. Port Washington: Kennikat Press, 1966. 